\title{
Transcriptome Analysis of Long Non-Coding RNA in the Bovine Mammary Gland Following Dietary Supplementation with Linseed Oil and Safflower Oil
}

\author{
Eveline M. Ibeagha-Awemu ${ }^{1, *(\mathbb{D})}$, Ran $\mathrm{Li}^{1,2}{ }^{1}$, Pier-Luc Dudemaine ${ }^{1}$, Duy N. Do ${ }^{1,3}$ and \\ Nathalie Bissonnette ${ }^{1}$ (D) \\ 1 Agriculture and Agri-Food Canada, Sherbrooke Research and Development Centre, \\ Sherbrooke, QC J1M 0C8, Canada; ran.li1986@hotmail.com (R.L.); pier-luc.dudemaine@canada.ca (P.-L.D.); \\ ngoc.d.do@mail.mcgill.ca (D.N.D.); nathalie.bissonnette@canada.ca (N.B.) \\ 2 College of Animal Science and Technology, Northwest A\&F University, Yangling 712100, China \\ 3 Department of Animal Science, McGill University, Ste-Anne-De-Bellevue, QC H9X 3V9, Canada \\ * Correspondence: eveline.ibeagha-awemu@canada.ca; Tel.: +1-819-780-7249
}

Received: 9 October 2018; Accepted: 2 November 2018; Published: 15 November 2018

\begin{abstract}
This study aimed to characterize the long non-coding RNA (lncRNA) expression in the bovine mammary gland and to infer their functions in dietary response to 5\% linseed oil (LSO) or 5\% safflower oil (SFO). Twelve cows (six per treatment) in mid lactation were fed a control diet for 28 days followed by a treatment period (control diet supplemented with 5\% LSO or 5\% SFO) of 28 days. Mammary gland biopsies were collected from each animal on day-14 (D-14, control period), D+7 (early treatment period) and D+28 (late treatment period) and were subjected to RNA-Sequencing and subsequent bioinformatics analyses. Functional enrichment of lncRNA was performed via potential cis regulated target genes located within $50 \mathrm{~kb}$ flanking regions of lncRNAs and having expression correlation of $>0.7$ with mRNAs. A total of 4955 lncRNAs ( 325 known and 4630 novel) were identified which potentially cis targeted 59 and 494 genes in LSO and SFO treatments, respectively. Enrichments of cis target genes of lncRNAs indicated potential roles of lncRNAs in immune function, nucleic acid metabolism and cell membrane organization processes as well as involvement in Notch, cAMP and TGF- $\beta$ signaling pathways. Thirty-two and 21 lncRNAs were differentially expressed (DE) in LSO and SFO treatments, respectively. Six genes (KCNF1, STARD13, BCL6, NXPE2, HHIPL2 and $M M D$ ) were identified as potential cis target genes of six DE lncRNAs. In conclusion, this study has identified lncRNAs with potential roles in mammary gland functions and potential candidate genes and pathways via which lncRNAs might function in response to LSO and SFA.
\end{abstract}

Keywords: long non-coding RNA; bovine mammary gland; linseed oil; safflower oil; lipid metabolism; fatty acid synthesis; cis-regulation

\section{Introduction}

Advances in high throughput RNA sequencing technologies and computational prediction techniques have enabled the discovery of an abundant class of non-coding RNA (ncRNA) species with emerging roles in gene regulation. Among these, long non-coding RNA (lncRNA) generally considered as RNA molecules $>200$ nucleotides (nts) are known to participate in a diverse set of biological processes including genomic imprinting, $\mathrm{X}$ chromosome inactivation, cell differentiation and development, cancer metastasis, immunity, disease and ageing [1-9]. LncRNA mediate these processes through diverse mechanisms including acting as scaffolds, decoys or signals, regulation of gene expression in cis or trans and antisense interference or by epigenetic regulation, organization of protein complexes, cell-cell signaling, allosteric regulation of proteins as well as genome targeting [7,10-12]. 
To date, a large number of lncRNA genes, enabled by continued developments in high-throughput sequencing methodologies, have been identified in the genomes of human ( $n=96,308)$, mouse $(n=87,774)$, cow $(n=22,227)$, rat $(n=22,217)$, gorilla $(n=15,095)$, other animals and model organisms (http:/ / www.bioinfo.org/noncode/analysis.php, accessed on 03 April 2018). Although the function of majority of lncRNAs are unknown, the mode of action of a few like $\mathrm{X}$ inactive specific transcript (XIST, functions in X chromosome inactivation, chromatin modification etc.) $[7,13,14]$, HOX transcript antisense RNA (HOTAIR, functions in positional identity, regulate gene expression in trans and is associated with a variety of cancers) [15-17] and metastasis associated lung adenocarcinoma transcript 1 (MALAT1, functions in nuclear structure organization and is associated with a variety of cancers etc.) [18] are well characterized. In bovine, only a few studies have examined the occurrence of IncRNAs in muscle [19], skin [20], expressed sequence tag (EST) data [21,22], across 18 tissues [23] and in the mammary gland [24]. Although it has been predicted that bovine ncRNAs including lncRNAs are abundant, primarily intergenic and associated with regulatory genes [22], little is known about the functions of lncRNAs in the bovine genome and the lncRNA atlas of the different cell types and tissues remain to be explored. A recent study has suggested that some lncRNAs play a role in translation control of target mRNA (messenger RNA) during development of bovine early embryos [4] as well as development processes in calf gut at the early part of life [25].

Numerous studies in humans and mice have shown evidence of a role for lncRNA in mammary development and disease [26]. Pregnancy-induced non coding RNA (PINC) is the first lncRNA shown to be differentially expressed in the mammary gland of a pregnancy simulated rat model [27]. Further work showed that the expression of PINC is temporally and spatially controlled in response to developmental stimuli in vivo and loss-of-function analysis suggest roles in cell survival and regulation of cell-cycle progression in the mammary gland [28]. Zfas1 also known as ZNFX1 antisense RNA 1 is a lncRNA localized in the ducts and alveoli of the mammary gland whose expression is differentially regulated during different stages of pregnancy, lactation and involution [29]. Furthermore, knockdown of Zfas1 in a mammary epithelial cell line (HC11 cells) promoted increased cellular proliferation and differentiation and thus is a key player in the regulation of mammary alveolar development and epithelial cell differentiation [29]. Unlike lncRNA, more efforts have been directed at characterizing microRNA (miRNA, another class of ncRNA) expression and potential regulatory roles in the bovine mammary gland [30-37]. However, the occurrence and roles of lncRNAs in the bovine mammary gland is largely unknown and remain to be explored. Recently, Tong et al. [24] identified 184 lncRNAs (intergenic) in the bovine mammary gland including 36 lincRNAs co-located with 172 milk related quantitative trait loci (QTL) and one lncRNA co-located within a mastitis QTL region. Moreover, IncRNAs have been shown to play roles in dietary response in different species including human [38-40], mouse [41], pig [42] and calf [43]. LncRNA roles in dietary responses might be through various processes such as metabolic control [40], glucose homeostasis [40] or hypoxia-mediated metastasis [44]. Recently, Weikard et al. [43] identified 270 differentially expressed lncRNAs in the jejunum mucosa of calves fed two different milk diets and suggested that the lncRNAs might function by modulating biological processes related to energy metabolism pathways and cellular signaling processes influencing the intestinal epithelial cell barrier function.

It is well documented that bovine milk fat contains isomers (e.g., conjugated linoleic acid (CLA)) that positively influence human health $[45,46]$. Furthermore, bovine milk fat can be modified to increase the contents of its beneficial components [46]. Particularly, many studies have shown that unsaturated fatty acids enriched dietary supplementation with plant oils (e.g., linseed oil, corn oil, canola oil, safflower oil) and fish oil significantly increased the concentrations of milk beneficial fatty acids such as CLA [47-51]. Previously, we identified numerous differentially expressed genes and miRNAs in mammary gland tissues of cows following dietary supplementation with unsaturated fatty acids enriched diets $[32,52,53]$. The functions of lncRNAs in this dietary response are not known. In order to shed more light on lncRNA occurrence in the bovine genome, we characterized the lncRNA expression in the bovine mammary gland and examined its expression pattern in response to diets 
rich in unsaturated fatty acids. Moreover, we also performed lncRNA function enrichment via their potential cis regulated target genes.

\section{Results}

\subsection{Expressed LncRNAs in the Bovine Mammary Gland}

One hundred base pairs paired-end RNA sequencing of 36 libraries generated a total of 1.2 billion reads. About $87.2 \%$ of reads mapped to unique/multiple positions on the bovine genome UMD3.1 built. Of these, $96.5 \%$ mapped to unique positions and were further processed while reads that mapped to multiple positions $(3.2 \%)$ and discordant alignments $(0.38 \%)$ were discarded. A total of 27,967 potential transcripts were identified. Since lncRNA expression is generally low as compared to mRNA, only lncRNAs with DESeq 2 normalized counts $\geq 5$ and present in at least $10 \%$ of our libraries were considered as truly expressed and also used in DE analysis. Consequently, $72.29 \%(20,218)$ of potential lncRNA transcripts failed this screening step and were not further considered.

A total of 4955 lncRNA genes (7749 lncRNA transcripts) equivalent to 325 known and 4630 novel lncRNA genes were identified (Supplementary file 1). Using FPKM (fragments per kilo base of transcript per million mapped reads) normalization, 13 novel and 15 known lncRNAs were highly expressed (0.55 to 11.56 FPKM values for novel or 0.21 to 11.93 FPKM values for known lncRNAs) in the bovine mammary gland (Figure 1A).

(A) Highly expressed IncRNAs

(B) Chromosomal distribution of IncRNA

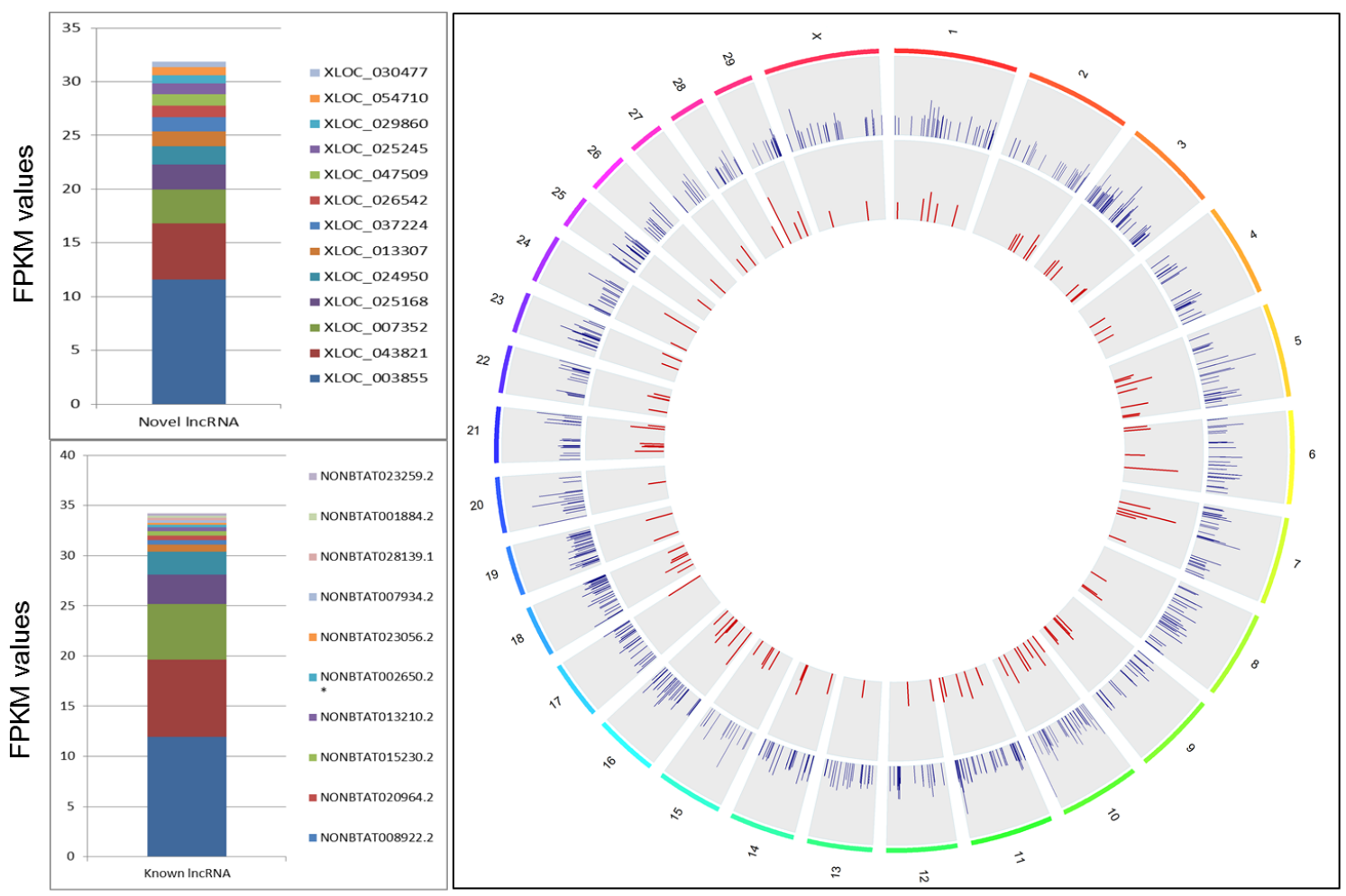

Figure 1. (A) Fifteen known and 13 novel highly expressed lncRNAs in the bovine mammary gland. FPKM values ranged from 0.55 to 11.56 or 0.21 to 11.93 for novel and known highly expressed lncRNAs, respectively. (B) Intuitive map of lncRNA distribution across bovine chromosomes (outermost circle, different colors). The inner circle (blue lines) represents novel lncRNAs and the innermost circle (red lines) represents known lncRNAs. The height of the line is proportional to the expression level (FPKM) and only those with FPKM $>0.02$ are shown. 
The most highly expressed known lncRNAs, NONBTAT026075.2 (FPKM $=11.93)$ and NONBTAT026069.2 (FPKM $=7.69$ ) are located on the mitochondria $(\mathrm{Mt})$ DNA. The highest number of novel lncRNAs are located on bovine chromosome (BTA) 3, 5, 7,8, 10, 18, 19 and X (209 to 258 lncRNAs) and known lncRNAs on BTA 3 and 10 (20 each) (Figure 1B, Supplementary file 2).

Expression level is a feature that distinguishes lncRNAs from mRNAs. Using FPKM normalization, we showed that the mean expression level of mRNA transcripts from the same data was 3.6 as compared to 0.30 for lncRNA (Figure 2A).
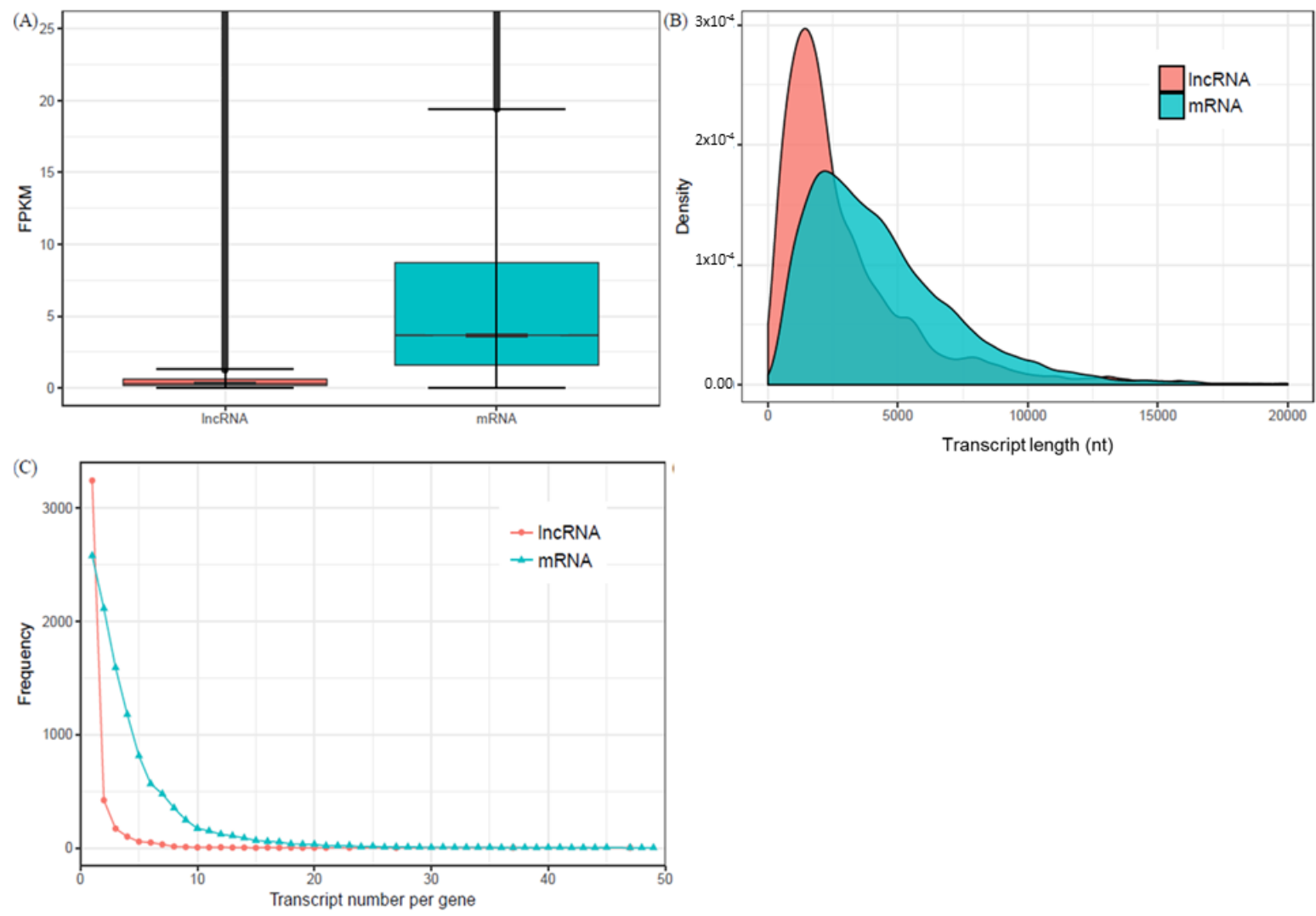

Figure 2. Features of identified lncRNA transcripts compared with transcripts of protein-coding genes. (A) Mean expression level of protein-coding mRNA transcripts is 3.6 compared to 0.30 for lncRNA. (B) LncRNA transcript length distribution compared with protein-coding mRNA. (C) Transcript number per lncRNA gene compared with protein-coding mRNA.

\subsection{Characteristics of Expressed LncRNAs}

LncRNAs are generally regarded as RNA molecules $>200 \mathrm{nts}$. The length distribution of identified lncRNA transcripts ranged from 200 to over 10,000 nts (Figure 2B, Supplementary file 3a). The majority (45.11\%) were between 200 and $999 \mathrm{nts}$ followed by 1000 to $2499 \mathrm{nts}(37.54 \%)$ while $17.34 \%$ were $\geq 2500$ nts long. One known lncRNA was however $<200$ nts long. Compared with mRNA transcripts from the same data [53], transcript length of majority of mRNA was between 500 and 7000 nts (Figure 2B).

The genomic location of a lncRNA is important as it may give clues to its functions. Thus, identified lncRNAs were classified according to their genomic location and expression direction into 11 classes (Supplementary file 3c). As expected, $62.38 \%$ of lncRNA transcripts were intergenic and located at $>1 \mathrm{~kb}$ (kilo base pairs) away from the nearest gene. This was followed by an appreciable number $(23.86 \%)$ of transcripts located in such a way that one or more of their exons overlapped with the exons of protein coding genes. LncRNA transcripts located within a one $\mathrm{kb}$ region upstream of protein coding genes and transcribed in the same or opposite direction constituted $8.74 \%$. In comparison, 
fewer lncRNAs (1.54\%) were located within one kb downstream of protein coding genes. LncRNAs located in the introns of genes were very few $(2.17 \%)$, as well as lncRNAs with intron containing mRNAs $(1.32 \%)$.

LncRNA like mRNA due to alternative splicing events can occur in multiple forms or transcripts. Majority of lncRNAs were composed of one transcript (85.17\%) followed by two transcripts $(5.45 \%)$ (Figure 2C, Supplementary file 3b). Similarly, majority of mRNA transcripts were mostly composed of one transcript (23.47\%) followed by 2 (19.23\%), 3 (14.48\%) and $4(10.72 \%)$ transcripts (Figure 2C, Supplementary file $3 \mathrm{~b})$. Some $\ln \mathrm{RNAs}$ and mRNAs were however composed of $>26$ transcripts.

\subsection{Function Enrichment via Potential cis Target Genes of IncRNAs}

Correlation analysis of lncRNA and mRNA expression identified 59 and 494 potential cis target genes (mRNAs) for lncRNAs in LSO and SFO treatments, respectively (Supplementary file 4). Among them, 38 genes were common to both treatments. A total of 67 (49 biological process gene ontology (GO) terms, 9 cellular components GO terms and 9 molecular functions GO terms) and 15 (12 biological process GO terms, 2 cellular components GO terms and 1 molecular functions GO term) were enriched for cis target genes of lncRNAs in SFO and LSO treatments, respectively (Tables 1 and 2 and Supplementary file 5). The most enriched GO terms were GO:1904375 (regulation of protein localization to cell periphery, $p=3.6 \times 10^{-4}$ ) for LSO and GO:0048294(negative regulation of isotype switching to IgE isotypes, $p=2.6 \times 10^{-3}$ ) for SFO. Moreover, 2 and 11 KEGG pathways were also enriched for LSO and SFO cis target genes at uncorrected $p$-value $<0.05$, respectively and SNARE interactions in vesicular transport pathway was common to both treatments (Figure 3). The SNARE interaction in vesicular transport pathway was also the most significantly enriched pathway for both LSO and SFO cis target genes (Figure 3).

Table 1. Gene ontologies enriched for cis target genes of lncRNAs in LSO treatments.

\begin{tabular}{|c|c|c|c|c|}
\hline GOID & GO Term & Ontology Source & $p_{-}$Value & p_FDR \\
\hline GO:1904375 & $\begin{array}{l}\text { Regulation of protein } \\
\text { localization to cell periphery }\end{array}$ & GO_BP & $8.40 \times 10^{-5}$ & $3.60 \times 10^{-4}$ \\
\hline GO:1903729 & $\begin{array}{l}\text { Regulation of plasma } \\
\text { membrane organization }\end{array}$ & GO_BP & $1.10 \times 10^{-4}$ & $3.80 \times 10^{-4}$ \\
\hline GO:1903076 & $\begin{array}{l}\text { Regulation of protein } \\
\text { localization to plasma } \\
\text { membrane }\end{array}$ & GO_BP & $7.20 \times 10^{-5}$ & $4.60 \times 10^{-4}$ \\
\hline GO:0060412 & $\begin{array}{l}\text { Ventricular septum } \\
\text { morphogenesis }\end{array}$ & GO_BP & $2.00 \times 10^{-4}$ & $5.40 \times 10^{-4}$ \\
\hline GO:0048546 & $\begin{array}{l}\text { Digestive tract } \\
\text { morphogenesis }\end{array}$ & GO_BP & $4.40 \times 10^{-4}$ & $8.30 \times 10^{-4}$ \\
\hline GO:0030858 & $\begin{array}{c}\text { Positive regulation of } \\
\text { epithelial cell differentiation }\end{array}$ & GO_BP & $6.90 \times 10^{-4}$ & $1.00 \times 10^{-3}$ \\
\hline GO:0060411 & $\begin{array}{l}\text { Cardiac septum } \\
\text { morphogenesis }\end{array}$ & GO_BP & $1.00 \times 10^{-3}$ & $1.30 \times 10^{-3}$ \\
\hline GO:0003281 & $\begin{array}{l}\text { Ventricular septum } \\
\text { development }\end{array}$ & GO_BP & $1.00 \times 10^{-3}$ & $1.30 \times 10^{-3}$ \\
\hline GO:0055006 & Cardiac cell development & GO_BP & $1.20 \times 10^{-3}$ & $1.40 \times 10^{-3}$ \\
\hline GO:0048663 & Neuron fate commitment & GO_BP & $1.30 \times 10^{-3}$ & $1.40 \times 10^{-3}$ \\
\hline GO:0048708 & Astrocyte differentiation & GO_BP & $1.40 \times 10^{-3}$ & $1.40 \times 10^{-3}$ \\
\hline GO:0002040 & Sprouting angiogenesis & GO_BP & $1.40 \times 10^{-3}$ & $1.40 \times 10^{-3}$ \\
\hline GO:0055038 & $\begin{array}{l}\text { Recycling endosome } \\
\text { membrane }\end{array}$ & GO_CC & $4.30 \times 10^{-5}$ & $5.50 \times 10^{-4}$ \\
\hline GO:0031201 & SNARE complex & GO_CC & $6.60 \times 10^{-4}$ & $1.00 \times 10^{-3}$ \\
\hline GO:0005484 & SNAP receptor activity & GO_MF & $2.20 \times 10^{-4}$ & $4.90 \times 10^{-4}$ \\
\hline
\end{tabular}

GO_BP: Biological process GO term, GO_CC:Cellular component GO term, GO_MF: Molecular function GO term. 
Table 2. Gene ontologies enriched for cis target genes of lncRNAs in SFO treatments.

\begin{tabular}{|c|c|c|c|c|}
\hline GOID & GO Term & Ontology Source & $p_{-}$Value & $p_{-}$FDR \\
\hline GO:0048294 & $\begin{array}{l}\text { Negative regulation of isotype switching to } \\
\text { IgE isotypes }\end{array}$ & GO_BP & $1.50 \times 10^{-5}$ & $2.60 \times 10^{-3}$ \\
\hline GO:0045910 & Negative regulation of DNA recombination & GO_BP & $1.10 \times 10^{-5}$ & $4.20 \times 10^{-3}$ \\
\hline GO:0045829 & Negative regulation of isotype switching & GO_BP & $5.90 \times 10^{-5}$ & $7.00 \times 10^{-3}$ \\
\hline GO:0010633 & $\begin{array}{c}\text { Negative regulation of epithelial cell } \\
\text { migration }\end{array}$ & GO_BP & $8.60 \times 10^{-5}$ & $7.70 \times 10^{-3}$ \\
\hline GO:0006396 & RNA processing & GO_BP & $1.00 \times 10^{-4}$ & $7.70 \times 10^{-3}$ \\
\hline GO:0002262 & Myeloid cell homeostasis & GO_BP & $2.20 \times 10^{-4}$ & $1.10 \times 10^{-2}$ \\
\hline GO:0000018 & Regulation of DNA recombination & GO_BP & $3.20 \times 10^{-4}$ & $1.10 \times 10^{-2}$ \\
\hline GO:0030218 & Erythrocyte differentiation & GO_BP & $3.00 \times 10^{-4}$ & $1.10 \times 10^{-2}$ \\
\hline GO:1902679 & $\begin{array}{l}\text { Negative regulation of RNA biosynthetic } \\
\text { process }\end{array}$ & GO_BP & $2.10 \times 10^{-4}$ & $1.20 \times 10^{-2}$ \\
\hline GO:0048289 & Isotype switching to $\operatorname{IgE}$ isotypes & GO_BP & $4.90 \times 10^{-4}$ & $1.50 \times 10^{-2}$ \\
\hline GO:0048293 & $\begin{array}{c}\text { Regulation of isotype switching to IgE } \\
\text { isotypes }\end{array}$ & GO_BP & $4.90 \times 10^{-4}$ & $1.50 \times 10^{-2}$ \\
\hline GO:0045646 & Regulation of erythrocyte differentiation & GO_BP & $6.20 \times 10^{-4}$ & $1.70 \times 10^{-2}$ \\
\hline GO:0034101 & Erythrocyte homeostasis & GO_BP & $6.20 \times 10^{-4}$ & $1.80 \times 10^{-2}$ \\
\hline GO:0002638 & $\begin{array}{l}\text { Negative regulation of immunoglobulin } \\
\text { production }\end{array}$ & GO_BP & $7.70 \times 10^{-4}$ & $1.80 \times 10^{-2}$ \\
\hline GO:0045654 & $\begin{array}{c}\text { Positive regulation of megakaryocyte } \\
\text { differentiation }\end{array}$ & GO_BP & $7.70 \times 10^{-4}$ & $1.80 \times 10^{-2}$ \\
\hline GO:0045892 & $\begin{array}{c}\text { Negative regulation of transcription, } \\
\text { DNA-templated }\end{array}$ & GO_BP & $7.60 \times 10^{-4}$ & $1.90 \times 10^{-2}$ \\
\hline GO:0060840 & Artery development & GO_BP & $9.60 \times 10^{-4}$ & $2.00 \times 10^{-2}$ \\
\hline GO:0016071 & mRNA metabolic process & GO_BP & $1.20 \times 10^{-3}$ & $2.40 \times 10^{-2}$ \\
\hline GO:1903706 & Regulation of hemopoiesis & GO_BP & $1.60 \times 10^{-3}$ & $2.70 \times 10^{-2}$ \\
\hline GO:0010720 & Positive regulation of cell development & GO_BP & $1.80 \times 10^{-3}$ & $2.80 \times 10^{-2}$ \\
\hline GO:0060602 & Branch elongation of an epithelium & GO_BP & $1.90 \times 10^{-3}$ & $2.80 \times 10^{-2}$ \\
\hline GO:0002829 & $\begin{array}{c}\text { Negative regulation of type } 2 \text { immune } \\
\text { response }\end{array}$ & GO_BP & $2.10 \times 10^{-3}$ & $3.00 \times 10^{-2}$ \\
\hline GO:0003158 & Endothelium development & GO_BP & $2.30 \times 10^{-3}$ & $3.20 \times 10^{-2}$ \\
\hline GO:0010632 & Regulation of epithelial cell migration & GO_BP & $2.50 \times 10^{-3}$ & $3.20 \times 10^{-2}$ \\
\hline GO:0006260 & DNA replication & GO_BP & $3.70 \times 10^{-3}$ & $3.40 \times 10^{-2}$ \\
\hline GO:0002064 & Epithelial cell development & GO_BP & $2.70 \times 10^{-3}$ & $3.40 \times 10^{-2}$ \\
\hline GO:0060442 & $\begin{array}{l}\text { Branching involved in prostate gland } \\
\text { morphogenesis }\end{array}$ & GO_BP & $2.80 \times 10^{-3}$ & $3.40 \times 10^{-2}$ \\
\hline GO:0045623 & $\begin{array}{l}\text { Negative regulation of T-helper cell } \\
\text { differentiation }\end{array}$ & GO_BP & $2.80 \times 10^{-3}$ & $3.40 \times 10^{-2}$ \\
\hline GO:0045648 & $\begin{array}{c}\text { Positive regulation of erythrocyte } \\
\text { differentiation }\end{array}$ & GO_BP & $3.60 \times 10^{-3}$ & $3.40 \times 10^{-2}$ \\
\hline GO:0035561 & Regulation of chromatin binding & GO_BP & $3.10 \times 10^{-3}$ & $3.60 \times 10^{-2}$ \\
\hline GO:1903708 & Positive regulation of hemopoiesis & GO_BP & $3.40 \times 10^{-3}$ & $3.60 \times 10^{-2}$ \\
\hline GO:0045620 & $\begin{array}{l}\text { Negative regulation of lymphocyte } \\
\text { differentiation }\end{array}$ & GO_BP & $3.20 \times 10^{-3}$ & $3.70 \times 10^{-2}$ \\
\hline GO:0070076 & Histone lysine demethylation & GO_BP & $4.70 \times 10^{-3}$ & $3.80 \times 10^{-2}$ \\
\hline GO:1903573 & $\begin{array}{l}\text { Negative regulation of response to } \\
\text { endoplasmic reticulum stress }\end{array}$ & GO_BP & $4.90 \times 10^{-3}$ & $3.80 \times 10^{-2}$ \\
\hline GO:1902105 & Regulation of leukocyte differentiation & GO_BP & $4.40 \times 10^{-3}$ & $3.80 \times 10^{-2}$ \\
\hline GO:0030968 & $\begin{array}{l}\text { Endoplasmic reticulum unfolded protein } \\
\text { response }\end{array}$ & GO_BP & $5.60 \times 10^{-3}$ & $4.20 \times 10^{-2}$ \\
\hline GO:0016577 & Histone demethylation & GO_BP & $6.10 \times 10^{-3}$ & $4.30 \times 10^{-2}$ \\
\hline GO:1902106 & $\begin{array}{l}\text { Negative regulation of leukocyte } \\
\text { differentiation }\end{array}$ & GO_BP & $6.20 \times 10^{-3}$ & $4.30 \times 10^{-2}$ \\
\hline GO:0016447 & $\begin{array}{l}\text { Somatic recombination of immunoglobulin } \\
\text { gene segments }\end{array}$ & GO_BP & $5.90 \times 10^{-3}$ & $4.30 \times 10^{-2}$ \\
\hline GO:0006349 & $\begin{array}{l}\text { Regulation of gene expression by genetic } \\
\text { imprinting }\end{array}$ & GO_BP & $6.60 \times 10^{-3}$ & $4.50 \times 10^{-2}$ \\
\hline GO:0002467 & Germinal center formation & GO_BP & $6.60 \times 10^{-3}$ & $4.50 \times 10^{-2}$ \\
\hline GO:0045064 & T-helper 2 cell differentiation & GO_BP & $6.60 \times 10^{-3}$ & $4.50 \times 10^{-2}$ \\
\hline GO:0045652 & Regulation of megakaryocyte differentiation & GO_BP & $6.60 \times 10^{-3}$ & $4.50 \times 10^{-2}$ \\
\hline GO:0001568 & Blood vessel development & GO_BP & $7.20 \times 10^{-3}$ & $4.70 \times 10^{-2}$ \\
\hline GO:0034620 & Cellular response to unfolded protein & GO_BP & $7.10 \times 10^{-3}$ & $4.70 \times 10^{-2}$ \\
\hline GO:0006482 & Protein demethylation & GO_BP & $7.70 \times 10^{-3}$ & $4.80 \times 10^{-2}$ \\
\hline GO:0050869 & Negative regulation of B cell activation & GO_BP & $7.70 \times 10^{-3}$ & $4.80 \times 10^{-2}$ \\
\hline GO:2000241 & Regulation of reproductive process & GO_BP & $8.20 \times 10^{-3}$ & $4.90 \times 10^{-2}$ \\
\hline GO:0048872 & Homeostasis of number of cells & GO_BP & $7.70 \times 10^{-3}$ & $4.90 \times 10^{-2}$ \\
\hline
\end{tabular}


Table 2. Cont.

\begin{tabular}{|c|c|c|c|c|}
\hline GOID & GO Term & Ontology Source & p_Value & p_FDR \\
\hline GO:0031252 & Cell leading edge & GO_CC & $8.30 \times 10^{-4}$ & $1.80 \times 10^{-2}$ \\
\hline GO:0031256 & Leading edge membrane & GO_CC & $1.50 \times 10^{-3}$ & $2.50 \times 10^{-2}$ \\
\hline GO:0001726 & Ruffle & GO_CC & $1.40 \times 10^{-3}$ & $2.60 \times 10^{-2}$ \\
\hline GO:0042581 & Specific granule & GO_CC & $3.80 \times 10^{-3}$ & $3.30 \times 10^{-2}$ \\
\hline GO:0032039 & Integrator complex & GO_CC & $3.50 \times 10^{-3}$ & $3.50 \times 10^{-2}$ \\
\hline GO:0031253 & Cell projection membrane & GO_CC & $3.40 \times 10^{-3}$ & $3.70 \times 10^{-2}$ \\
\hline GO:0098858 & Actin-based cell projection & GO_CC & $4.40 \times 10^{-3}$ & $3.80 \times 10^{-2}$ \\
\hline GO:0005902 & Microvillus & GO_CC & $5.80 \times 10^{-3}$ & $4.30 \times 10^{-2}$ \\
\hline GO:0055037 & Recycling endosome & GO_CC & $6.60 \times 10^{-3}$ & $4.40 \times 10^{-2}$ \\
\hline GO:0051731 & Polynucleotide $5^{\prime}$-hydroxyl-kinase activity & GO_MF & $2.80 \times 10^{-4}$ & $1.20 \times 10^{-2}$ \\
\hline GO:0008134 & Transcription factor binding & GO_MF & $1.40 \times 10^{-3}$ & $2.60 \times 10^{-2}$ \\
\hline GO:0051020 & GTPase binding & GO_MF & $3.60 \times 10^{-3}$ & $3.40 \times 10^{-2}$ \\
\hline GO:0019787 & Ubiquitin-like protein transferase activity & GO_MF & $3.50 \times 10^{-3}$ & $3.60 \times 10^{-2}$ \\
\hline GO:0030374 & $\begin{array}{l}\text { Ligand-dependent nuclear receptor } \\
\text { transcription coactivator activity }\end{array}$ & GO_MF & $3.30 \times 10^{-3}$ & $3.70 \times 10^{-2}$ \\
\hline GO:0005089 & $\begin{array}{l}\text { Rho guanyl-nucleotide exchange factor } \\
\text { activity }\end{array}$ & GO_MF & $4.80 \times 10^{-3}$ & $3.80 \times 10^{-2}$ \\
\hline GO:0060589 & Nucleoside-triphosphatase regulator activity & GO_MF & $4.70 \times 10^{-3}$ & $3.90 \times 10^{-2}$ \\
\hline GO:0035591 & Signaling adaptor activity & GO_MF & $5.80 \times 10^{-3}$ & $4.30 \times 10^{-2}$ \\
\hline GO:0031267 & Small GTPase binding & GO_MF & $7.80 \times 10^{-3}$ & $4.80 \times 10^{-2}$ \\
\hline
\end{tabular}

GO_BP: Biological process GO term, GO_CC:Cellular component GO term, GO_MF: Molecular function GO term.

\section{Linseed oil treatment}

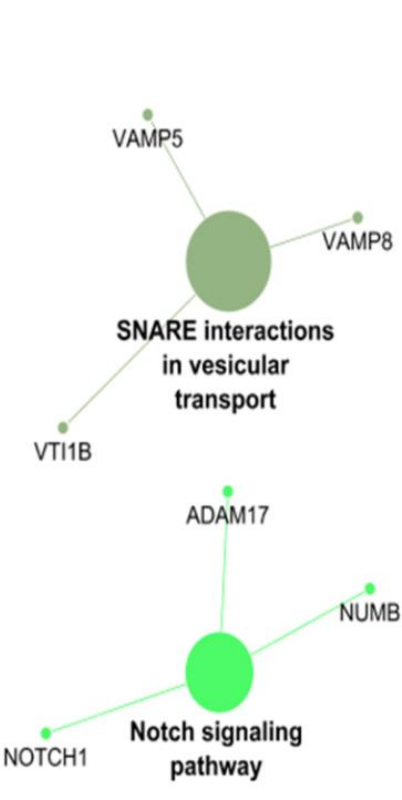

\section{Safflower oil treatment}

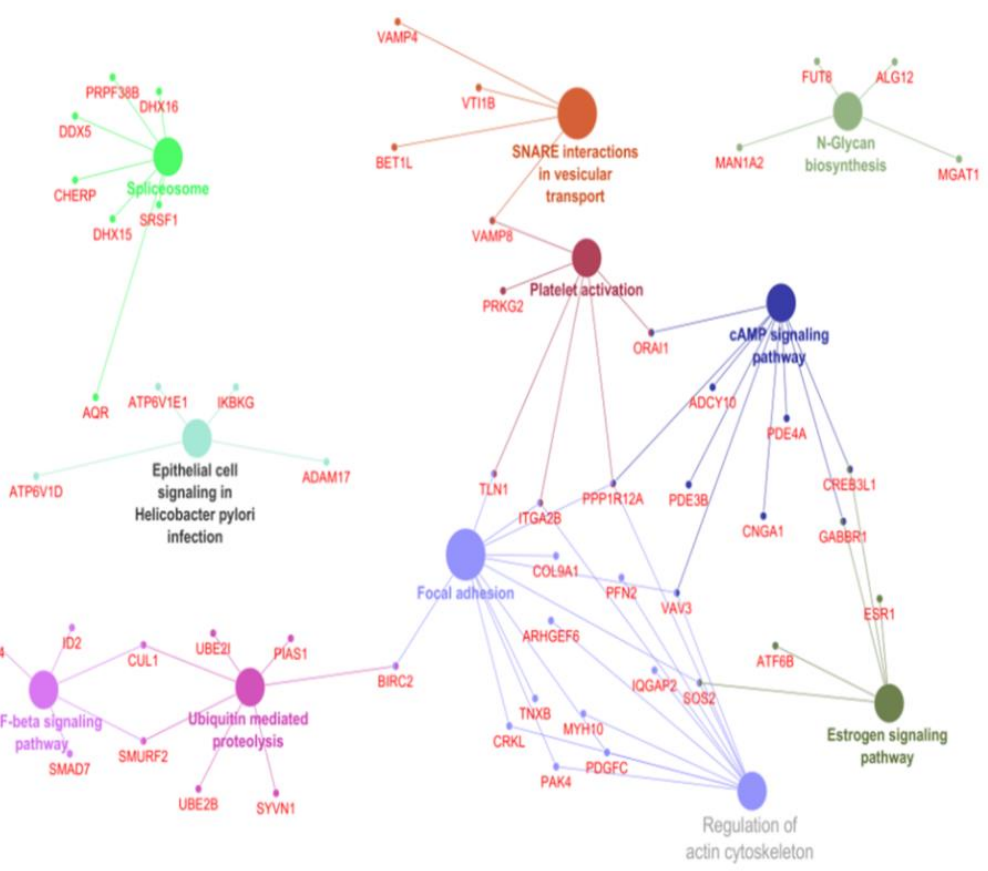

Figure 3. Enriched KEGG pathways for predicted cis target genes of lncRNAs.

\subsection{Effects of Diets Rich in Unsaturated Fatty Acids on IncRNA Expression}

Differential gene expression results of the effect of diets on lncRNA expression are shown in Tables 3 and 4. A total of 32 (11 up-regulated and 21 down-regulated) and 21 (4 up-regulated and 17 down-regulated) lncRNAs were differentially expressed (DE) in LSO and SFO treatments, respectively. Out of this number, seven are known lncRNAs. The highest number of DE lncRNAs was recorded after the first week of supplementation (D+7 vs. D+28) by LSO (21 lncRNAs) and SFO (19 lncRNAs). LncRNAs responded only to LSO (6 DE lncRNAs) at the onset of supplementation (D-14 vs. $\mathrm{D}+7)$ while no lncRNA was DE by SFO during this period. Also, few lncRNAs were DE between D-14 and D+28 (10 lncRNAs for LSO and 4 for SFO). 
Table 3. Differentially expressed lncRNAs in response to dietary supplementation with $5 \%$ linseed oil.

\begin{tabular}{|c|c|c|c|c|c|c|c|c|}
\hline Periods of Comparison & Known lncRNA Notation & Chr & Chr Start..End & Nearest Gene & FC & $\log 2 \mathrm{FC}$ & $p$-Value & Padj \\
\hline \multicolumn{9}{|l|}{ D-14 vs. D+7 } \\
\hline XLOC_044813 & $\begin{array}{l}\text { NONBTAT030934.1 } \\
\text { NONBTAG014563.2 }\end{array}$ & 6 & 17675271..17680447 & - & $\begin{array}{c}- \\
2.749\end{array}$ & -1.459 & $2.247 \times 10^{-7}$ & 0.0010 \\
\hline XLOC_032807 & New & 26 & $33011966 . .33019072$ & - & 2.310 & 1.208 & $7.345 \times 10^{-7}$ & 0.0017 \\
\hline XLOC_041145 & $\begin{array}{l}\text { NONBTAT020143.2 } \\
\text { NONBTAG013424.2 }\end{array}$ & 4 & $95417314 . .95613931$ & - & $\begin{array}{c}- \\
2.190\end{array}$ & -1.131 & $3.393 \times 10^{-6}$ & 0.0051 \\
\hline $\begin{array}{l}\text { XLOC_021427 } \\
\text { XLOC_021420 }\end{array}$ & $\begin{array}{l}\text { New } \\
\text { New }\end{array}$ & $\begin{array}{l}19 \\
19\end{array}$ & $\begin{array}{l}31640546 . .31641078 \\
31604279 . .31663126\end{array}$ & - & $\begin{array}{l}-2.378 \\
-2.258\end{array}$ & $\begin{array}{l}-1.250 \\
-1.175\end{array}$ & $\begin{array}{l}8.409 \times 10^{-6} \\
3.207 \times 10^{-5}\end{array}$ & $\begin{array}{l}0.0095 \\
0.0289\end{array}$ \\
\hline XLOC_004564 & $\begin{array}{l}\text { NONBTAT002269.2 } \\
\text { NONBTAG013424.2 }\end{array}$ & 10 & $49527965 . .49605076$ & RORA (ENSBTAT00000021144) & 1.720 & 0.782 & 0.0001 & 0.0769 \\
\hline \multicolumn{9}{|l|}{$\mathrm{D}+7$ vs. $\mathrm{D}+28$} \\
\hline XLOC_050004 & New & 8 & 64796589..64820744 & - & $\begin{array}{c}- \\
2.160\end{array}$ & -1.111 & $4.666 \times 10^{-8}$ & 0.0001 \\
\hline XLOC_004564 & $\begin{array}{l}\text { NONBTAT002269.2 } \\
\text { NONBTAG001608.2 }\end{array}$ & 10 & $49527965 . .49605076$ & RORA (ENSBTAT00000021144) & $\begin{array}{c}- \\
1.848\end{array}$ & -0.886 & $1.084 \times 10^{-5}$ & 0.0065 \\
\hline XLOC_018587 & New & 18 & 11048799..11055932 & CRISPLD2 (ENSBTAT00000028221) & $\begin{array}{c}- \\
1.758\end{array}$ & -0.814 & $8.899 \times 10^{-6}$ & 0.0065 \\
\hline XLOC_049508 & New & 8 & $22729811 . .22734496$ & $\begin{array}{l}\text { ENSBTAG00000047195 } \\
\text { (ENSBTAT00000048617) }\end{array}$ & 2.063 & -1.045 & $8.973 \times 10^{-6}$ & 0.0065 \\
\hline XLOC_026857 & New & 21 & $31732594 . .31860453$ & FBXO22 (ENSBTAT00000003665) & $\begin{array}{c}- \\
1.471\end{array}$ & -0.557 & $2.408 \times 10^{-5}$ & 0.0116 \\
\hline XLOC_024438 & New & 2 & $134829905 . .134832425$ & - & $\begin{array}{c}- \\
1.821\end{array}$ & -0.865 & $7.330 \times 10^{-5}$ & 0.0196 \\
\hline XLOC_039327 & New & 3 & $114773040 . .114828419$ & - & $\begin{array}{c}- \\
1.696\end{array}$ & -0.762 & $6.304 \times 10^{-5}$ & 0.0196 \\
\hline XLOC_049790 & $\begin{array}{l}\text { NONBTAT031343.1 } \\
\text { NONBTAG022051.1 }\end{array}$ & 8 & $42264400 . .42279290$ & - & 1.873 & 0.905 & $6.640 \times 10^{-5}$ & 0.0196 \\
\hline XLOC_049791 & New & 8 & $42273319 . .42275306$ & - & 2.172 & 1.119 & $6.569 \times 10^{-5}$ & 0.0196 \\
\hline XLOC_049767 & New & 8 & $42141722 . .42245895$ & - & 1.911 & 0.934 & $8.906 \times 10^{-5}$ & 0.0214 \\
\hline XLOC_049792 & $\begin{array}{l}\text { NONBTAT031344.1 } \\
\text { NONBTAG016235.2 }\end{array}$ & 8 & $42279395 . .42321282$ & - & 2.032 & 1.023 & 0.0002 & 0.0410 \\
\hline XLOC_011302 & New & 14 & $84116708 . .84118510$ & - & 2.035 & 1.025 & 0.0002 & 0.0466 \\
\hline XLOC_030043 & New & 23 & $36290019 . .36292016$ & - & 1.691 & 0.758 & 0.0003 & 0.0467 \\
\hline XLOC_004276 & New & 10 & $26691672 . .26693523$ & - & 1.657 & 0.729 & 0.0003 & 0.0590 \\
\hline XLOC_007663 & New & 12 & $27541269 . .28034473$ & STARD13 (ENSBTAT00000029081) & $1 . \overline{3} 30$ & -0.411 & 0.0004 & 0.0592 \\
\hline
\end{tabular}


Table 3. Cont

\begin{tabular}{|c|c|c|c|c|c|c|c|c|}
\hline Periods of Comparison & Known lncRNA Notation & Chr & Chr Start..End & Nearest Gene & FC & $\log 2 \mathrm{FC}$ & $p$-Value & Padj \\
\hline XLOC_005960 & New & 11 & $86699810 . .86710266$ & - & 1.825 & -0.868 & 0.0006 & 0.0825 \\
\hline XLOC_014482 & New & 16 & $52617661 . .52619004$ & - & 1.634 & -0.708 & 0.0006 & 0.0825 \\
\hline XLOC_050157 & New & 8 & $77681842 . .77683706$ & - & $\begin{array}{c}- \\
1.940\end{array}$ & -0.956 & 0.0006 & 0.0825 \\
\hline XLOC_051249 & New & 8 & $84443959 . .84447116$ & - & $\begin{array}{c}- \\
1.683\end{array}$ & -0.751 & 0.0007 & 0.0825 \\
\hline XLOC_040832 & New & 4 & $66327795 . .66329807$ & - & $1 . \overline{-} 95$ & -0.922 & 0.0008 & 0.0913 \\
\hline XLOC_044269 & New & 5 & 100899101..100938587 & - & $\overline{-} 1.418$ & -0.504 & 0.0009 & 0.0985 \\
\hline \multicolumn{9}{|l|}{ D-14 vs. D+28 } \\
\hline XLOC_032807 & New & 26 & $33011966 . .33019072$ & - & 2.178 & 1.123 & $3.826 \times 10^{-6}$ & 0.0023 \\
\hline XLOC_040082 & New & 4 & $93460873 . .93469656$ & HIG2 (ENSBTAT00000045181) & 2.310 & 1.208 & $2.246 \times 10^{-6}$ & 0.0023 \\
\hline XLOC_044264 & New & 5 & $100888960 . .100892632$ & - & 2.079 & -1.056 & $4.000 \times 10^{-6}$ & 0.0023 \\
\hline XLOC_044269 & New & 5 & 100899101..100938587 & - & 1.529 & -0.613 & $4.937 \times 10^{-5}$ & 0.0152 \\
\hline XLOC_045228 & New & 6 & $87225278 . .87228405$ & - & $1 . \overline{-} 97$ & -0.924 & $4.182 \times 10^{-5}$ & 0.0152 \\
\hline XLOC_053316 & New & Mt & 2.360 & - & $\begin{array}{c}- \\
1.970\end{array}$ & -0.978 & $5.330 \times 10^{-5}$ & 0.0152 \\
\hline XLOC_049790 & $\begin{array}{l}\text { NONBTAT031343.1 } \\
\text { NONBTAG022051.1 }\end{array}$ & 8 & $42264400 . .42279290$ & - & 1.813 & 0.858 & 0.0001 & 0.0349 \\
\hline XLOC_054333 & New & $x$ & $123683291 . .124283250$ & $\begin{array}{l}\text { ENSBTAG00000048092 } \\
\text { (ENSBTAT00000030016) }\end{array}$ & 1.580 & 0.660 & 0.0004 & 0.0847 \\
\hline XLOC_002555 & New & 1 & $153149175 . .153164789$ & - & $\overline{-} \cdot \overline{1}$ & -0.766 & 0.0006 & 0.0973 \\
\hline XLOC_049791 & New & 8 & 42273319..42275306 & - & 1.957 & 0.969 & 0.0005 & 0.0973 \\
\hline
\end{tabular}


Table 4. Differentially expressed lncRNAs in response to dietary supplementation with $5 \%$ safflower oil.

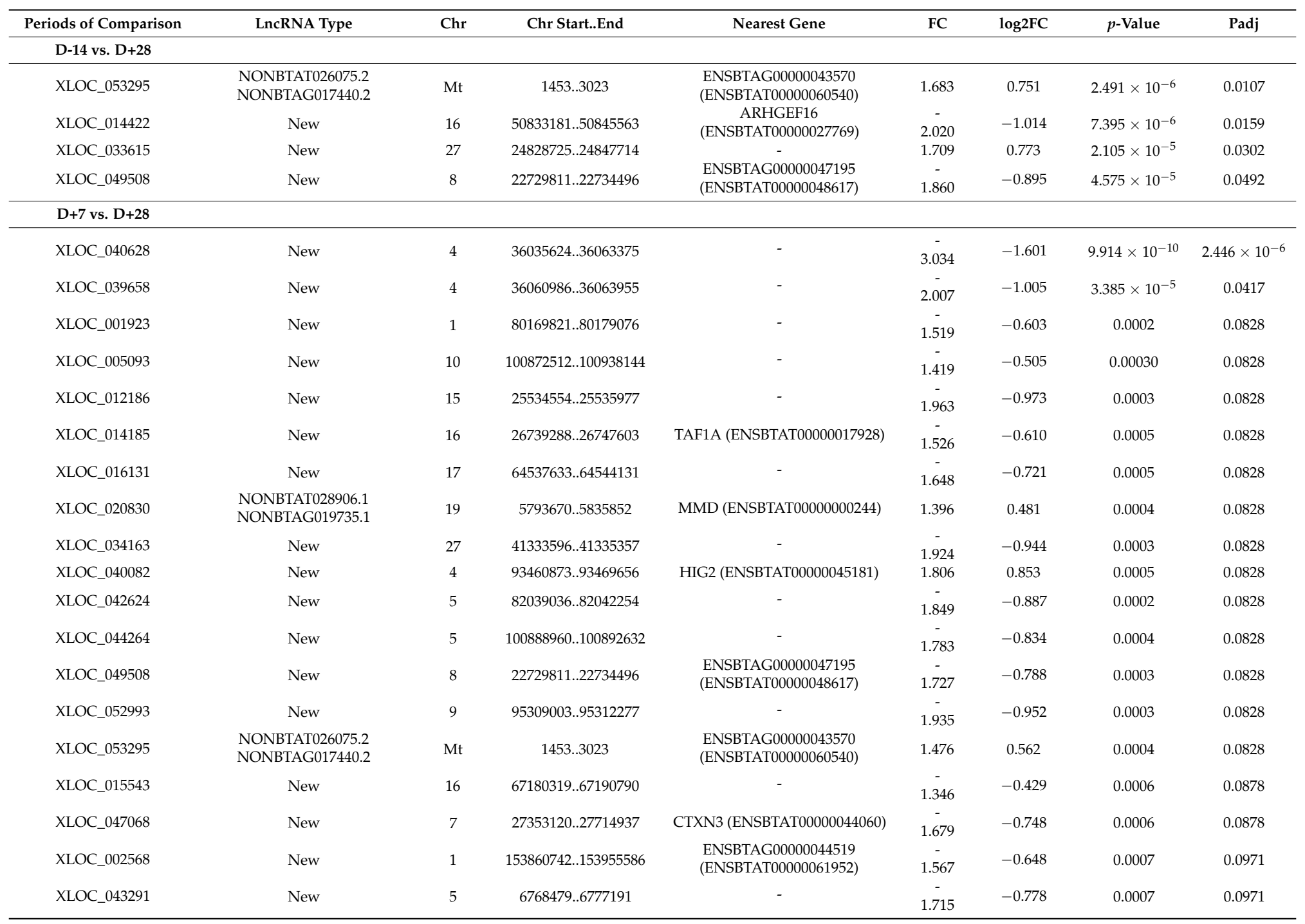


Comparisons between days for LSO showed that DE lncRNAs were mostly specific to each pair of comparison with only three common DE lncRNAs between D+7 versus D+28 and D-14 versus D+28 (XLOC_049790 (NONBTAT031343.1), XLOC_049791 and XLOC_044269) and one each between D-14 versus D+7 and D+7 versus D+28 (XLOC_004564 (NONBTAT002269.2)) and D-14 versus D+7 and D-14 versus D+28 (XLOC_032807) (Figure 4). For SFO, two lncRNAs (XLOC_053295 (NONBTAT026075.2) and XLOC_049508) were common between D-14 versus D+28 and d D+7 versus D+28 (Figure 4). Two and four cis target genes were predicted for DE lncRNAs in LSO and SFO treatments, respectively (Table 5). High correlations were observed between XLOC_007663 and STARD13 $(r=0.89)$ gene in LSO treatment and between XLOC_020830 and MMD gene $(r=0.94)$ in SFO treatment.
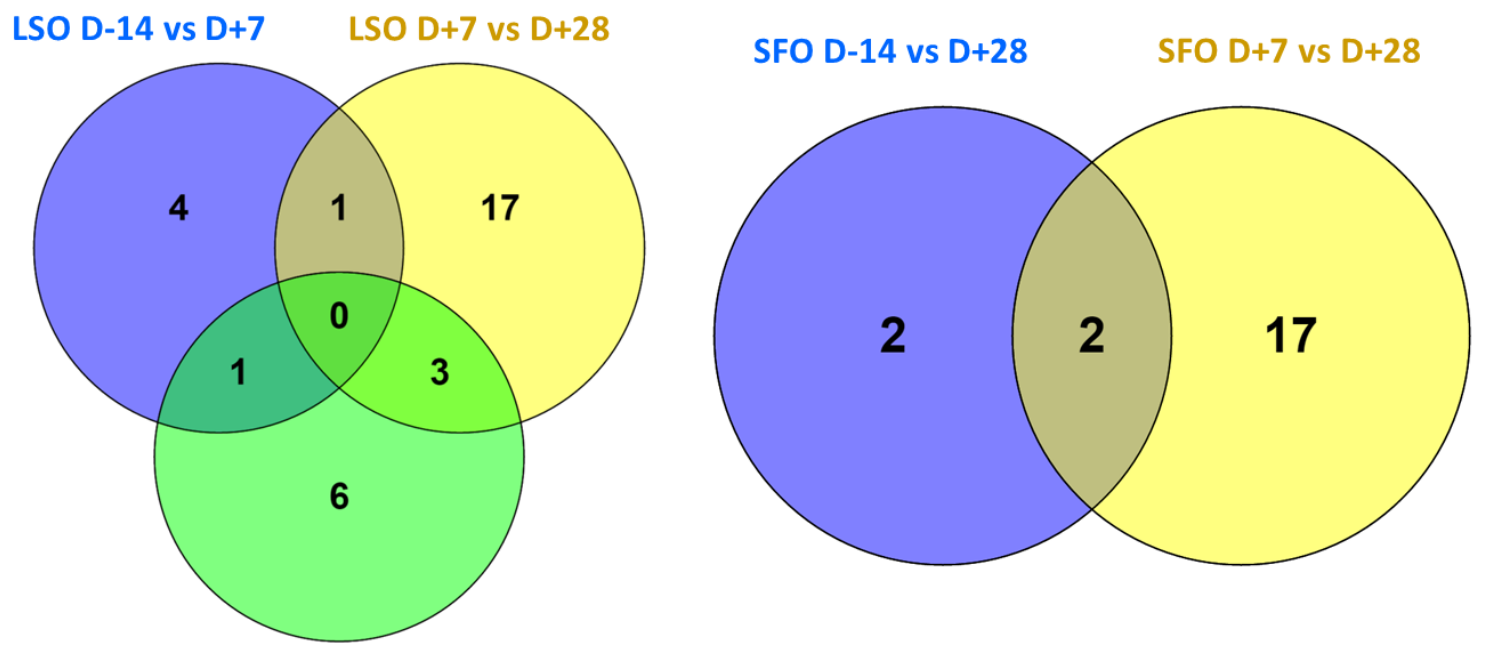

LSO D-14 vs D+28

Figure 4. Unique and common significantly ( $p$-value $\mathrm{BH}<0.1)$ differentially expressed lncRNAs between periods of comparison.

Table 5. Potential cis target genes for differentially expressed lncRNAs in linseed oil and safflower oil treatments.

\begin{tabular}{cccccccc}
\hline Treatment & LncRNA & Gene & Correlation & $\boldsymbol{p}$-Value & Chromosome & Gene.Start & Gene.End \\
\hline Linseed oil & XLOC_005960 & KCNF1 & 0.821379 & $2.93 \times 10^{-5}$ & 11 & 86759338 \\
Linseed oil & XLOC_007663 & STARD13 & 0.894839 & $5.38 \times 10^{-7}$ & 12 & 27866074 \\
Safflower oil & XLOC_001923 & BCL6 & 0.797951 & $7.25 \times 10^{-5}$ & 1 & 80179482 & 802033238 \\
Safflower oil & XLOC_012186 & NXPE2 & 0.822692 & $2.77 \times 10^{-5}$ & 15 & 25515542 & 25524857 \\
Safflower oil & XLOC_014185 & HHIPL2 & 0.739728 & 0.00045 & 16 & 26713225 & 26741364 \\
Safflower oil & XLOC_020830 & MMD & 0.940505 & $6.54 \times 10^{-9}$ & 19 & 5819716 & 5840124 \\
\hline
\end{tabular}

2.5. Reversed Transcribed PCR (RT-PCR) Verification of the Detection of IncRNA and Real Time Quantitative $P C R$ ( $q P C R)$ Verification of the Expression Level of IncRNA

Using RT-PCR, we verified the presence of four lncRNAs (XLOC_003855, XLOC_053295 (NONBTAT026075.2), XLOC_014422 and XLOC_049508) in three different samples (Supplementary file 6). RT-PCR products were of expected sizes (Supplementary file 6), thus confirming RNA-Seq results of lncRNA detection. Moreover, we verified the expression levels of two lncRNAs (XLOC_049508 and XLOC_040628) by real time qPCR (Figure 5). XLOC_049508 and XLOC_040628 were both expressed at $>4$ fold change, compared to $>2$ fold change by RNA-seq, thus confirming RNA-seq results. 


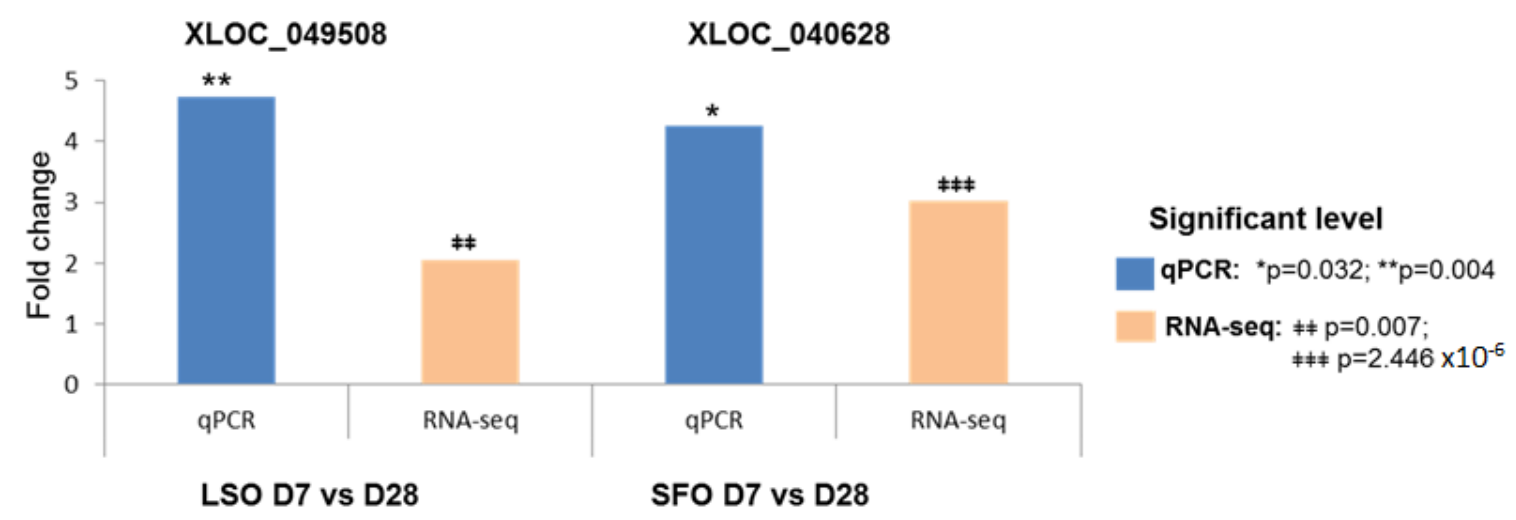

Figure 5. Results of qPCR validation of the expression levels of two lncRNAs and compared to RNA-seq results. $\mathrm{LSO}=$ linseed oil; $\mathrm{SFO}=$ safflower oil; $\mathrm{D}=$ day.

\section{Discussion}

Previously, we showed a reduction in milk fat yield of $30.38 \%$ and $32.42 \%$ in response to $5 \%$ LSO and 5\% SFO, respectively, accompanied by increased concentrations of some monounsaturated and polyunsaturated fatty acids in milk, differential regulation of genes with roles in lipid synthesis/metabolism [53], differential miRNA expression [32] and co-expression network of miRNAs [52]. In the present study, we have characterized the lncRNA repertoire of the bovine mammary gland in response to LSO and SFO.

A total of 325 known and 4630 novel lncRNAs were identified in this study. Identified lncRNAs were generally less expressed and of smaller sizes compared to mRNA transcripts. Studies on the annotation of human lncRNAs have reported lower expression, smaller size and fewer exons for lncRNAs as compared to mRNAs [54,55] thus supporting our observations. The transcript number per lncRNA gene as compared to mRNA in this study followed the same pattern reported earlier for human [55]. Majority of identified lncRNA transcripts in this study are located in the intergenic regions of protein coding genes (Table S3e). This observation is consistent with previous studies that have reported that lncRNAs are principally located in the intergenic region of genes while a lesser percentage overlap protein coding genes [22,54,55]. Qu and Adelson [22] noted that $67.4 \%$ of intergenic bovine ncRNAs had a neighbor gene within $20 \mathrm{~kb}$, with significant number within $5 \mathrm{~kb}$ flanking regions of genes. Studies have suggested/demonstrated that lncRNAs may act in cis or trans to regulate the activities of neighboring genes [56-61]. It has been shown that functional clustering of neighbor genes within $5 \mathrm{~kb}$ of intergenic ncRNAs resulted in over-representation of regulatory genes [22]. The expression of intergenic lncRNAs was reported to be highly correlated with the expression of neighboring genes within $10 \mathrm{~kb}$ [54]. It should be noted that co-expression of lncRNA and mRNA could be due to a true cis effect of the lncRNA on the mRNA or due to nearby transcriptional activity of surrounding open chromatin [54,62].

Some of the highly expressed lncRNAs identified in this study (13 novel and 15 known) have been detected in bovine tissues, skin and EST data from many developmental stages [20-22]. Given that lncRNAs are generally less expressed, the relative high expression levels of the 28 lncRNAs suggest potential roles in the bovine mammary gland. However, validation of their functional significance in the bovine mammary gland merits further investigations. Since it is known that lncRNAs may regulate in cis or trans the expression of protein coding genes [56-61] and since the functions of most bovine lncRNAs are still unknown, we predicted the potential functions of detected lncRNAs via correlated cis located mRNAs in the transcriptome data from the same animals. Various GO terms for the potential cis target genes of lncRNAs were enriched in different processes (Tables 1 and 2) which might reflect diverse functions of lncRNAs in the bovine mammary gland. The most enriched GO term for LSO (GO:1904375-regulation of protein localization to cell periphery) does not appear to have a direct functional link with mammary lipid synthesis but it might be important for tissue functioning by 
modulating the frequency, rate or extent of protein localization to cell periphery. In the SFO treatment, the most enriched term (GO:0048294-negative regulation of isotype switching to IgE isotypes) as well as other enriched GO terms (GO:0002829, GO:0045623 and GO:0045829) showed involvement in immune regulation. The functions of lncRNAs in immunity are well documented $[63,64]$. Recently, enrichment results by Tong et al. [24] suggest that lncRNAs might play roles in the regulation of immune genes and potentially contribute to disease resistance, such as mastitis in cows. Yang et al. [65] reported involvement of lncRNA H19 in TGF- $\beta 1$-induced epithelial to mesenchymal transition in bovine epithelial cells and suggested its potential role in immunity and bovine mastitis. In another experiment, Ma et al. [66] reported many lncRNAs that were DE during bovine viral diarrhea virus infection with potential roles in immune functions. As expected, IncRNA target genes were significantly enriched for biological process GO terms involved in regulation of RNA processing (GO:0006396 and GO:1902679) as well as DNA recombination (GO:0045910, GO:0000018). In fact, to perform their functions, lncRNAs might bind to their target genes [67], therefore it is not surprising that the nucleic acids regulation GO terms were enriched. A notable KEGG pathway enriched for LSO treatment was Notch signaling pathway. Notch signaling pathway is important in mammary gland development $[68,69]$. Previously, we reported that Notch signaling pathway was enriched for target genes of miRNAs in the regulation of milk yield and component traits [70]. It is not clear which specific lncRNAs could be regulating this pathway or how they are involved in the regulation of mammary gland functions. However, the lncRNA HOTAIR has been reported to target the Notch signaling pathway in cervical cancer cells [71]. The SNARE interaction in vesicular transport pathway was significantly enriched for cis target genes of lncRNAs in both LSO and SFO treatments. This pathway is important for mediating intracellular destination of transport vesicles [72] as well as membrane fusion $[73,74]$ but it is not clear what role it plays in the regulation of mammary gland functions. Other notable pathways enriched for SFO IncRNA cis target genes were cAMP and TGF- $\beta$ signaling pathways. cAMP was recently identified as an enriched pathway for lncRNA target genes in the bovine mammary gland [24] while TGF- $\beta$ signaling pathway, known to have important immune functions, was reported as an important pathway for lactation persistency [75] as well as an enriched pathway for target genes of DE miRNAs during a lactation curve [76].

Differential gene expression results showed that nutrients rich in unsaturated fatty acids had an effect on lncRNA expression. A comparison of DE lncRNAs between LSO and SFO treatments indicated that more lncRNAs were DE by LSO as compared to SFO and in particular, no lncRNA was DE after one week of SFO supplementation (D-14 vs. D+7). This is similar to our previous observation on mRNA transcriptome of the same data that showed a greater impact of LSO over SFO on gene expression [53]. Also, the mRNA transcriptome data indicated involvement of LSO and SFO DE genes in similar (molecular transport, small molecule biochemistry, lipid metabolism) and different (LSO: cell death and survival, protein synthesis, cellular growth and proliferation and amino acid metabolism; SFO: energy production, cellular movement, cell cycle and carbohydrate metabolism) functions and pathways, which could be due to the different degree of unsaturation of the main fatty acids in LSO and SFO [53]. LSO is rich in $\alpha$-linolenic acid ( 3 double bonds in their structure) while SFO is rich in linoleic acid ( 2 double bonds), which resulted in different intermediates of biohydrogenation in the rumen thus affecting differently the pathways of lipid metabolism and other functions. It is known that the profile of ruminal biohydrogenation intermediates are influenced by the type of diet $[77,78]$ and that pathways related to lipid metabolism have been significantly changed due to diet supplementation [79]. Thus, the observed differential expression of lncRNAs might reflect the change in their functions in response to the type of diet supplement (LSO or SFO). To the best of our knowledge, there are no studies related to lncRNAs expression/function in response to lipid supplements in the mammary gland, so further studies are needed in this area. Moreover, some DE lncRNAs in this study have been previously characterized in bovine [20,22]. These results and our observation suggest regulatory roles of lncRNA in many biological processes including mammary gland functions. Moreover, we also identified six potential cis target genes (KCNF1, STARD13, BCL6, NXPE2, HHIPL2 
and $M M D$ ) for DE lncRNAs (Table 5). These genes are involved in lipid metabolism (STARD13), molecular transport (KCNF1), immune processes / disease (MMD and BCL6) and in epigenetic processes (STARD13). STARD13 encodes for a member of StAR-related lipid transfer (START) proteins which play important roles in the regulation of intracellular lipid metabolism [80]. MiRNA-125b was shown to induce metastasis in MCF-7 and MDA-MB-231 breast cancer cells through targeting of STARD13 [81]. The monocyte to macrophage differentiation associated $(M M D)$ gene showed the highest level of correlation $\left(p\right.$-value $\left.=6.54 \times 10^{-9}\right)$ with a lncRNA $($ XLOC_020830 $)$ in SFO treatment. Roles for MMD in the positive regulation of ERK and Akt activation and TNF- $\alpha$ and nitric oxide production in macrophages have been demonstrated [82].

It should be noted that, transcripts of the main proteins (CSN1S1, CSN1S2, CSN2, CSN3, LGB and LALBA and GLYCAM1) in milk constituted $79.45 \%$ of the read counts in mammary tissue transcriptome [53] which could impede detection of lowly expressed transcripts. Therefore, a higher sequence read count per sample or depletion of the transcripts of these main proteins might be required to better characterize a class of lowly expressed genes like lncRNAs in mammary tissue. As with many differential gene expression studies, the number of DE genes detected relies on the choice of methodologies (data filtering, read count normalization and comparison between different groups) and selection of methods for correction of multiple testing and threshold for declaration of significant $p$-values. In this study, we chose the Benjamini and Hochberg [83] moderate conservative method for multiple testing which is widely used in the field to avoid losing important DE genes as observed with more conservative methods like Bonferroni correction. It is well documented that the choice of database for enrichment analyses and the methods to test enriched terms also influence results obtained [84,85]. In this study, a hypergeometric test was applied for testing of GO term enrichment using ClueGO [86] platform. This approach has been widely used in the literature and also in our previous study [70]. The potential functions of identified lncRNAs were predicted through inference of the correlation of lncRNA and mRNA expression. However, it is important to note that an observed correlation does not necessarily mean causal relationship. The cis target genes predicted based on expression correlation needs to be experimentally functionally verified to confirm their functions.

\section{Materials and Methods}

\subsection{Experimental Animals and Tissue Sampling}

Animal care, management and use procedures were according to the national codes of practice for the care and handling of farm animals (http:/ / www.nfacc.ca/codes-of-practice) and approved by the Animal Care and Ethics Committee of Agriculture and Agri-Food Canada (CPA \#402, 04 April, 2012).

The experiment was conducted at the dairy barn of the Sherbrooke Research and Development Centre of Agriculture and Agri-Food Canada. Procedures for animal management and sampling have been reported in our companion papers on the same animals [32,52,53]. In summary, twelve high producing ( $35 \pm 10 \mathrm{~kg}$ milk/day) Canadian Holstein cows in mid-lactation (150 \pm 50 days in milk) were separated based on parity and days in milk and randomly allocated to one of two treatments: (1) linseed oil treatment (LSO) six cows fed a control diet composed of a total mixed ration of corn and grass silages (50:50) and concentrates supplemented with 5\% LSO (on dry matter (DM) bases) and (2) safflower oil treatment (SFO) six cows fed the control diet supplemented with 5\% SFO (DM) for 28 days. The treatment period ( $D+1$ to $D+28$ ) was preceded by a control period (D-28 to D-1) of 28 days during which time all the animals were on the control diet. The composition of experimental diets is listed in Supplementary file 7. Mammary gland biopsies were harvested from all the animals at three different times during the experimental periods: D-14 (control period), D+7 (7th day after onset of treatment, early treatment period) and D+28 (28th day of treatment, late treatment period) according to an established protocol [87]. Milk samples were collected weekly for the measurement of fat content and fatty acid profiles and the results have been reported [53]. 


\subsection{RNA Isolation and Sequencing}

Total RNA was isolated from $50 \mathrm{mg}$ /biopsy sample with miRNeasy Kit (Qiagen Inc., Toronto, ON, Canada) according to manufacturer's protocol. Purified RNA was DNase digested with Turbo DNase Kit (Ambion Inc., Foster City, CA, USA) to eliminate DNA contamination. RNA concentration was measured with Nanodrop ND-1000 spectrophotometer (NanoDrop Technologies, Wilmington, DE, USA). The RNA 6000 Nano Labchip Kit (Agilent Technologies, Santa Clara, CA, USA) was used to assess the quality of RNA on an Agilent 2100 Bioanalyzer (Agilent Technologies, Santa Clara, CA, USA). The RNA integrity number of all samples was high and ranged from 7.99 to 9.5.

Thirty-six Libraries (LSO = 18 libraries, SFO = 18 libraries) were each generated from $250 \mathrm{ng}$ total RNA using the TruSeq stranded mRNA Kit (Illumina Inc., San Diego, CA, USA) according to manufacturer's protocol. The Quant-iT ${ }^{\mathrm{TM}}$ PicoGreen ${ }^{\circledR}$ dsDNA Assay Kit (Life Technologies, Burlington, ON, Canada) and the Kapa Illumina GA with the Revised Primers-SYBR Fast Universal Kit (D-Mark Biosciences, Toronto, ON, Canada) were used to quantify generated libraries. Fragment size of libraries was determined on Agilent 2100 Bioanalyzer (Agilent Technologies). The cBot instrument (Illumina Inc.) was used to perform cluster formation on the flow cell. Libraries were multiplexed in equal ratios (six/lane) and sequenced in the form of 50-cycle $100 \mathrm{bp}$ paired-end reads, on a HiSeq 2000 system (Illumina Inc.) running HCS software v2.2.58. After sequencing, demultiplexed FASTQ files were generated by allowing up to one mismatch in the index. Libraries were generated and sequenced by McGill University and Genome Quebec Innovation Centre (MUGQIC, http:/ / gqinnovationcenter.com/).

\subsection{RNA-Sequence Read Alignment and Identification of IncRNA}

RNA-Seq reads from each sample (total of 36) were trimmed using trimmomatic software v0.32 to keep reads longer than $32 \mathrm{bp}$ with a minimum phred score of 30 and to remove adaptor sequences. Reads were then aligned to the bovine genome (UMD3.1) [88] with Tophat (v2.0.11) [89] using default parameters. Uniquely mapped and properly paired reads were assembled with Cufflinks (v2.1.1) [90] and using Ensembl bovine gene annotation release 79. Assembled transcripts from all samples were merged into one using Cuffmerge (Cufflinks v2.1.1) to generate a unique set of all transcripts. Transcripts with a length $<200 \mathrm{nt}$ were removed and remaining transcripts compared with Ensembl bovine gene annotation (release 79) to remove transcripts overlapping with known protein coding and noncoding genes (mRNA, tRNA, rRNA, snRNA, snoRNA, miRNA) using Cuffcompare. mRNA transcripts were retained as a separate data set for use in comparing lncRNA expression pattern. Transcripts with class code " $\mathrm{i}$ " (an exon falling into an intron of reference transcript), " $\mathrm{o}$ " (generic exonic overlap with reference transcripts), " $u$ " (intergenic transcript) and " $x$ " (exonic overlap with reference transcript on the opposite strand) were retained. Retained transcripts were evaluated for their coding potentials using Coding-Non-Coding Index (CNCI) program [91]. CNCI is effective for distinguishing protein-coding and non-coding nucleotide sequences by profiling adjoining nucleotide triplets. Those transcripts assigned with a negative CNCI score were classified as candidate non-coding transcripts. The coding potential of candidate non-coding transcripts was further assessed with Coding Potential Assessment Tool (CPAT) [92]. CPAT was trained with available bovine known protein-coding transcripts from Ensembl bioMart and bovine non-coding sequences (NONCODE2016) [93] to build a logistic regression model. The resulting CPAT coding probability score for the transcripts ranges between 0 and 1 with a higher score indicating a higher coding potential. We chose a cut-off value of 0.4 for determining protein coding probability.

The remaining transcripts were then blasted against the Swiss-prot database to remove those with a hit $\left(e\right.$ value $\left.<1 \times 10^{-5}\right)$ using usearch [94]. Retained transcripts were compared with known bovine lncRNA annotation from NONCODE2016 database [93,95]. Those transcripts with class codes of " $=$ " (complete match with reference transcript), "c" (contained in reference transcript) and " $j "$ (novel isoform of reference transcript) were classified as known bovine lncRNA whereas the rest were classified as novel lncRNA. The identified lncRNA were further classified into 11 classes with the reference of Ensembl bovine protein coding gene annotation. 


\subsection{Gene Ontology and Pathways Enrichment for IncRNA cis Target Genes}

Since lncRNAs can cis regulate mRNAs [56-61], we performed enrichments for lncRNA cis regulatory functions by using mRNA transcriptome data obtained from the same animals [53]. For each IncRNA, Pearson correlation of its expression value with that of each mRNA was calculated. The closest coding genes within $50 \mathrm{~kb}$ upstream and downstream of lncRNAs were mined using BEDTools v2.25.0 program [96]. The genes were considered potential cis target genes of lncRNAs if in addition to their location (within a $50 \mathrm{~kb}$ window upstream or downstream of lncRNAs) they had a Pearson correlation of $>0.7$ with lncRNAs.

These cis target genes were submitted to the ClueGo plugin [86] in Cytoscape [97] for GO term and KEGG pathways enrichment analysis. Enriched pathways and GO terms were tested using a hypergeometric test which estimates enrichment by evaluating the overlap between genes in a given gene set (input gene list) followed by annotating genes to a GO term or pathway. The null hypothesis was 'the annotated GO term or pathway was irrelevant to the input list'. The $p$-value measures the significance of enrichment derived from the tail probability of observing numbers of DE genes annotated to the GO term or pathway. Enriched GO terms were declared significant at Benjamini and Hochberg [83] adjusted $p$-value $\leq 0.05$ while a lower threshold at uncorrected $p$-value $<0.05$ were considered significant for KEGG pathways enrichment.

\subsection{LncRNA Expression and Differential Gene Expression Analysis}

The expression of identified lncRNAs (known and novel) was quantified in each sample using HTSeq-count (version 0.6.1p1) with default settings (-s reverse). The raw read counts of retained transcripts of all libraries were then imported into DESeq2 [98] to identify differentially expressed lncRNAs. DESeq2 calculates a size factor for each sample to correct for library size and RNA composition bias. Those lncRNAs with DESeq 2 normalized counts $\geq 5$ in at least $10 \%$ of our libraries were considered as truly expressed. Significantly differentially expressed lncRNAs were defined as having a Benjamini and Hochberg adjusted $p$-value $<0.1$. The expression level of each lncRNA was determined as FPKM. To further illustrate the functions of lncRNA in the nutrient effects on mammary gland, the same procedure for enrichments using Clue GO was applied for cis target genes of lncRNAs DE by treatments.

\subsection{Reversed Transcribed (RT)-PCR}

Reversed transcribed- PCR was performed to verify the presence of IncRNAs detected by RNA sequencing. Primers for four randomly selected lncRNAs (XLOC_003855, XLOC_053295 (NONBTAT026075.2), XLOC_014422 and XLOC_049508) were designed using Integrated DNA Technologies Assay tool (https://www.idtdna.com/scitools/Applications/RealTimePCR/). The gene-specific primers used for detecting lncRNAs are shown in Supplementary file 6. Reverse transcription was performed with SuperScript ${ }^{\mathrm{TM}}$ II Reverse Transcriptase (Life Technologies Inc., Carlsbad, CA, USA), using 500 ng of the same total RNA used in RNA sequencing. cDNA templates were amplified in three different samples by PCR using Crimson Taq DNA polymerase (New England BioLabs, Whitby, ON, Canada). All PCR reactions were performed using the Veriti 96 well thermal cycler (Applied Biosystems, Foster City, CA, USA). An initial PCR gradient was done to determine the best annealing temperature for each primer pair. Thermal cycling condition was composed of an initial denaturation at $95^{\circ} \mathrm{C}$ for $4 \mathrm{~min}$ followed by 45 cycles of $30 \mathrm{~s}$ denaturation at $95^{\circ} \mathrm{C}, 1 \mathrm{~min}$ annealing at $52{ }^{\circ} \mathrm{C}$ and elongation at $72{ }^{\circ} \mathrm{C}$ for $30 \mathrm{~s}$. The final extension step was done at $72{ }^{\circ} \mathrm{C}$ for $5 \mathrm{~min}$. The PCR products ( $~ 300-600 \mathrm{bp}$ ) were run on 1.5\% agarose gel and visualized with Fusion FX (Birch House, Brambleside, Uckfield, UK). A 100bp ladder was run alongside the samples. 


\subsection{Real-Time qPCR Verification of IncRNA Expression}

Validation of the RNA-seq expression levels of two randomly selected DE lncRNAs was done using real-time quantitative PCR. Reverse transcription was performed with the SuperScript ${ }^{\mathrm{TM}}$ III Reverse Transcriptase (Life Technologies), using aliquots $(1 \mu \mathrm{g})$ of the same total RNA used in RNA-seq. The cDNA samples were diluted to $20 \mathrm{ng} / \mu \mathrm{L}$. Transcript-specific primers were designed using Integrated DNA Technologies RealTime qPCR Assay tool (https:/ / www.idtdna.com/scitools/ Applications/RealTimePCR/) (Supplementary file 8). Real-time PCR reaction mix was composed of $5 \mu \mathrm{L}$ Power SYBR ${ }^{\circledR}$ Green PCR Master Mix (Life Technologies Inc., Burlington, ON, Canada), $3 \mu \mathrm{L}$ cDNA, $300 \mathrm{nM}$ of each forward and reverse primers and 0.1 U AmpErase ${ }^{\circledR}$ Uracil N-Glycosylase (UNG, Life Technologies, Carlsbad, CA, USA). QPCR reactions were performed using the StepOnePlus ${ }^{\mathrm{TM}}$ Real-Time PCR System (Life Technologies). The thermal cycling conditions were composed of a step for UNG treatment at $25{ }^{\circ} \mathrm{C}$ for $5 \mathrm{~min}$ followed by an initial denaturation/activation step at $95{ }^{\circ} \mathrm{C}$ for $10 \mathrm{~min}, 45 \mathrm{cycles}$ at $95^{\circ} \mathrm{C}$ for $30 \mathrm{~s}, 60^{\circ} \mathrm{C}$ for $60 \mathrm{~s}$. The experiments were carried out in triplicate for each data point. The relative quantification of gene expression was determined using the $2^{-\Delta \Delta C t}$ method [99]. The fold change in gene expression was obtained following normalization to two reference genes, RPS15 and GAPDH. The stability of these reference genes have been previously tested [53].

\section{Conclusions}

A total of 4955 lncRNAs ( 325 known and 4630 novel) were identified including 32 (11 up-regulated and 21 down-regulated) and 21 (4 up-regulated and 17 down-regulated) lncRNAs differentially expressed in LSO and SFO treatments, respectively. The impact of LSO on IncRNA expression was early and also more potent as compared to SFO. GO and pathway analyses of lncRNA cis target genes suggest regulatory roles for lncRNAs in mammary gland functions, immune functions and metabolism/regulation of nucleic acid processes in the mammary gland. Furthermore, lncRNAs DE by LSO or SFO suggest potential regulatory roles in mammary lipid metabolism and synthesis of lipid/fatty acid. The identified lncRNAs will further enrich the catalogue of bovine lncRNAs and will contribute in the understanding of mammary gland functions and biology.

Supplementary Materials: Supplementary materials can be found at http:/ / www.mdpi.com/1422-0067/19/11/ 3610/s1. Supplementary file 1: Identified lncRNA read counts: (a) Novel lncRNAs, (b) gtf file of novel lncRNAs, (c) Known lncRNAs and (d) gtf file of known lncRNAs; Supplementary file 2: Chromosomal distribution of identified novel and known lncRNA genes; Supplementary file 3: (a) Length distribution of identified lncRNAs; (b) transcript distribution of identified lncRNAs compared with transcript distribution of protein coding genes; (c) Class distribution of lncRNAs. Supplementary file 4: Cis target genes of identified lncRNAs. Supplementary file 5: Gene ontology and KEGG pathways enriched for cis target genes of lncRNAs; Supplementary file 6: (A) LncRNA genes detected by RT-PCR in three different samples $(1,2,3)$. PCR products were of expected sizes; 349 bps for XLOC_003855 (i), 574 bps for XLOC_053295 (ii), 441 bps for XLOC_014422 (iii) and 319 bps for XLOC_049508 (iv). $M=100$ bp ladder. (B) Primer sequences used in RT-PCR. Supplementary file 7: Ingredients and chemical composition of the experimental diets. Supplementary file 8: Primer sequences used in real time quantitative PCR (qPCR).

Author Contributions: E.M.I.-A. designed the study with inputs from N.B., R.L., P.-L.D. and D.N.D. performed bioinformatics analysis of data. E.M.I.-A. drafted the manuscript. All authors revised and approved the final manuscript.

Funding: This research was funded by Agriculture and Agri-Food Canada, grant number J-000733.

Acknowledgments: Authors thank Adolf A. Ammah, Frederic Beaudoin and Lynda Marier for participating in the animal phase, Bridget Fomenky for performing PCR verifications and farm staff of Agriculture and Agri-Food Canada's Sherbrooke Research and Development Center for the animal care during the experimental period.

Conflicts of Interest: The authors declare no conflict of interest.

Availability of supporting data: The sequence data has been submitted to Gene Expression Omnibus database (BioProject ID: PRJNA301777) and is available through this link: http://www.ncbi.nlm.nih.gov/bioproject/ 301777. 


\section{Abbreviations}

\begin{tabular}{|c|c|}
\hline ANGPTL4 & Angiopoietin like 4 \\
\hline BCL6 & B-cell CLL/lymphoma 6 \\
\hline bp & Base pair \\
\hline BTA & Bovine chromosome \\
\hline CLA & Conjugated linoleic acid \\
\hline CNCI & Coding-Non-Coding Index \\
\hline CPAT & Coding Potential Assessment Tool \\
\hline $\mathrm{DE}$ & Differentially expressed \\
\hline $\mathrm{DM}$ & Dry matter \\
\hline ERK & Extracellular signal-regulated kinase \\
\hline EST & Expressed sequence tag \\
\hline FPKM & Fragments per kilo base of transcript per million mapped reads \\
\hline GAPDH & Glyceraldehyde-3-phosphate dehydrogenase \\
\hline GO & Geno ontology \\
\hline HHIPL2 & HHIP like 2 \\
\hline $\mathrm{kb}$ & Kilo base pairs \\
\hline KCNF1 & Potassium voltage-gated channel modifier subfamily F member 1 \\
\hline KEGG & Kyoto encyclopedia of genes and genomes \\
\hline LncRNA & Long non-coding RNA \\
\hline LSO & Linseed oil \\
\hline MALAT1 & Metastasis associated lung adenocarcinoma transcript 1 \\
\hline $\mathrm{Mb}$ & Mega base pairs \\
\hline miRNA & Micro RNA \\
\hline MMD & Macrophage differentiation associated \\
\hline mRNA & Messenger RNA \\
\hline Mt & Mitochondria \\
\hline ncRNA & Non-coding RNA \\
\hline nt & Nucleotides \\
\hline NXPE2 & Neurexophilin and PC-esterase domain family member 2 \\
\hline PINC & Pregnancy-induced non coding RNA \\
\hline QTL & Quantitative trait loci \\
\hline rRNA & ribosomal RNA \\
\hline RPS15 & Ribosomal protein S15 \\
\hline RT-PCR & Reverse transcription polymerase chain reaction \\
\hline SFO & Safflower oil \\
\hline snoRNA & Small nucleolar RNA \\
\hline snRNA & Small nuclear RNA \\
\hline STARD13 & StAR related lipid transfer domain containing 13 \\
\hline TNF- $\alpha$ & Tumor necrosis factor-alpha \\
\hline tRNA & Transfer RNA \\
\hline XIST & $X$ inactive specific transcript \\
\hline Zfas1 & ZNFX1 antisense RNA 1 \\
\hline ZNFX1 & Zinc finger NFX1-type containing 1 \\
\hline
\end{tabular}

\section{References}

1. Kretz, M.; Siprashvili, Z.; Chu, C.; Webster, D.; Zehnder, A.; Qu, K.; Lee, C.; Flockhart, R.; Groff, A.; Chow, J.; et al. Control of somatic tissue differentiation by the long non-coding RNA TINCR. Nature 2013, 493, 231-235. [CrossRef] [PubMed]

2. Satpathy, A.T.; Chang, H.Y. Long noncoding RNA in hematopoiesis and immunity. Immunity 2015, 42, 792-804. [CrossRef] [PubMed]

3. Fatica, A.; Bozzoni, I. Long non-coding RNAs: New players in cell differentiation and development. Nat. Rev. Genet. 2014, 15, 7-21. [CrossRef] [PubMed] 
4. Caballero, J.; Gilbert, I.; Fournier, E.; Gagne, D.; Scantland, S.; Macaulay, A.; Robert, C. Exploring the function of long non-coding RNA in the development of bovine early embryos. Reprod. Fertil. Dev. 2014, 27, 40-52. [CrossRef] [PubMed]

5. Devaux, Y.; Zangrando, J.; Schroen, B.; Creemers, E.E.; Pedrazzini, T.; Chang, C.-P.; Dorn, G.W., II; Thum, T.; Heymans, S. Long noncoding RNAs in cardiac development and ageing. Nat. Rev. Cardiol. 2015, 12, 415-425. [PubMed]

6. Hansji, H.; Leung, E.Y.; Baguley, B.C.; Finlay, G.J.; Askarian-Amiri, M.E. Keeping abreast with long non-coding RNAs in mammary gland development and breast cancer. Front. Genet. 2014, 5, 379. [CrossRef] [PubMed]

7. McHugh, C.A.; Chen, C.-K.; Chow, A.; Surka, C.F.; Tran, C.; McDonel, P.; Pandya-Jones, A.; Blanco, M.; Burghard, C.; Moradian, A.; et al. The Xist lncRNA interacts directly with sharp to silence transcription through HDAC3. Nature 2015, 521, 232-236. [CrossRef] [PubMed]

8. Flynn, R.A.; Chang, H.Y. Long noncoding RNAs in cell fate programming and reprogramming. Cell. Stem Cell 2014, 14, 752-761. [CrossRef] [PubMed]

9. Melissari, M.T.; Grote, P. Roles for long non-coding RNAs in physiology and disease. Pflügers Arch. 2016, 468, 945-958. [CrossRef] [PubMed]

10. Ulitsky, I.; Bartel, D.P. LincRNAs: Genomics, evolution, and mechanisms. Cell 2013, 154, 26-46. [CrossRef] [PubMed]

11. Quinn, J.J.; Chang, H.Y. Unique features of long non-coding RNA biogenesis and function. Nat. Rev. Genet. 2016, 17, 47-62. [CrossRef] [PubMed]

12. Geisler, S.; Coller, J. RNA in unexpected places: Long non-coding RNA functions in diverse cellular contexts. Nat. Rev. Mol. Cell. Biol. 2013, 14, 699-712. [CrossRef] [PubMed]

13. Wutz, A.; Jaenisch, R. A shift from reversible to irreversible $\mathrm{x}$ inactivation is triggered during es cell differentiation. Mol. Cell 2000, 5, 695-705. [CrossRef]

14. Wutz, A.; Rasmussen, T.P.; Jaenisch, R. Chromosomal silencing and localization are mediated by different domains of Xist RNA. Nat. Genet. 2002, 30, 167-174. [CrossRef] [PubMed]

15. Gupta, R.A.; Shah, N.; Wang, K.C.; Kim, J.; Horlings, H.M.; Wong, D.J.; Tsai, M.C.; Hung, T.; Argani, P.; Rinn, J.L.; et al. Long non-coding RNA hotair reprograms chromatin state to promote cancer metastasis. Nature 2010, 464, 1071-1076. [CrossRef] [PubMed]

16. Kogo, R.; Shimamura, T.; Mimori, K.; Kawahara, K.; Imoto, S.; Sudo, T.; Tanaka, F.; Shibata, K.; Suzuki, A.; Komune, S.; et al. Long noncoding RNA hotair regulates polycomb-dependent chromatin modification and is associated with poor prognosis in colorectal cancers. Cancer Res. 2011, 71, 6320-6326. [CrossRef] [PubMed]

17. Nie, Y.; Liu, X.; Qu, S.; Song, E.; Zou, H.; Gong, C. Long non-coding RNA hotair is an independent prognostic marker for nasopharyngeal carcinoma progression and survival. Cancer Sci. 2013, 104, 458-464. [CrossRef] [PubMed]

18. Gutschner, T.; Hammerle, M.; Eissmann, M.; Hsu, J.; Kim, Y.; Hung, G.; Revenko, A.; Arun, G.; Stentrup, M.; Gross, M.; et al. The noncoding RNA malat1 is a critical regulator of the metastasis phenotype of lung cancer cells. Cancer Res. 2013, 73, 1180-1189. [CrossRef] [PubMed]

19. Billerey, C.; Boussaha, M.; Esquerré, D.; Rebours, E.; Djari, A.; Meersseman, C.; Klopp, C.; Gautheret, D.; Rocha, D. Identification of large intergenic non-coding RNAs in bovine muscle using next-generation transcriptomic sequencing. BMC Genom. 2014, 15, 499. [CrossRef] [PubMed]

20. Weikard, R.; Hadlich, F.; Kuehn, C. Identification of novel transcripts and noncoding RNAs in bovine skin by deep next generation sequencing. BMC Genom. 2013, 14, 789. [CrossRef] [PubMed]

21. Huang, W.; Long, N.; Khatib, H. Genome-wide identification and initial characterization of bovine long non-coding RNAs from EST data. Anim. Genet. 2012, 43, 674-682. [CrossRef] [PubMed]

22. Qu, Z.; Adelson, D.L. Bovine ncRNAs are abundant, primarily intergenic, conserved and associated with regulatory genes. PLoS ONE 2012, 7, e42638. [CrossRef] [PubMed]

23. Koufariotis, L.T.; Chen, Y.-P.P.; Chamberlain, A.; Vander Jagt, C.; Hayes, B.J. A catalogue of novel bovine long noncoding RNA across 18 tissues. PLoS ONE 2015, 10, e0141225. [CrossRef] [PubMed]

24. Tong, C.; Chen, Q.; Zhao, L.; Ma, J.; Ibeagha-Awemu, E.M.; Zhao, X. Identification and characterization of long intergenic noncoding RNAs in bovine mammary glands. BMC Genom. 2017, 18, 468. [CrossRef] [PubMed] 
25. Ibeagha-Awemu, E.; Do, D.; Dudemaine, P.-L.; Fomenky, B.; Bissonnette, N. Integration of lncRNA and mRNA transcriptome analyses reveals genes and pathways potentially involved in calf intestinal growth and development during the early weeks of life. Genes 2018, 9, 142. [CrossRef] [PubMed]

26. Sandhu, G.K.; Milevskiy, M.J.G.; Wilson, W.; Shewan, A.M.; Brown, M.A. Non-coding RNAs in mammary gland development and disease. In Non-coding RNA and the Reproductive System; Wilhelm, D., Bernard, P., Eds.; Springer: Dordrecht, The Netherlands, 2016; pp. 121-153.

27. Ginger, M.R.; Gonzalez-Rimbau, M.F.; Gay, J.P.; Rosen, J.M. Persistent changes in gene expression induced by estrogen and progesterone in the rat mammary gland. Mol. Endocrinol. 2001, 15, 1993-2009. [CrossRef] [PubMed]

28. Ginger, M.R.; Shore, A.N.; Contreras, A.; Rijnkels, M.; Miller, J.; Gonzalez-Rimbau, M.F.; Rosen, J.M. A noncoding RNA is a potential marker of cell fate during mammary gland development. Proc. Natl. Acad. Sci. USA 2006, 103, 5781-5786. [CrossRef] [PubMed]

29. Askarian-Amiri, M.E.; Crawford, J.; French, J.D.; Smart, C.E.; Smith, M.A.; Clark, M.B.; Ru, K.; Mercer, T.R.; Thompson, E.R.; Lakhani, S.R.; et al. Snord-host RNA ZFAS1 is a regulator of mammary development and a potential marker for breast cancer. RNA 2011, 17, 878-891. [CrossRef] [PubMed]

30. Jin, W.; Ibeagha-Awemu, E.M.; Liang, G.; Beaudoin, F.; Zhao, X.; Guan, L.L. Transcriptome microRNA profiling of bovine mammary epithelial cells challenged with escherichia coli or staphylococcus aureus bacteria reveals pathogen directed microRNA expression profiles. BMC Genom. 2014, 15, 181. [CrossRef] [PubMed]

31. Le Guillou, S.; Marthey, S.; Laloë, D.; Laubier, J.; Mobuchon, L.; Leroux, C.; Le Provost, F. Characterisation and comparison of lactating mouse and bovine mammary gland mirnomes. PLoS ONE 2014, 9, e91938. [CrossRef] [PubMed]

32. Li, R.; Beaudoin, F.; Ammah, A.; Bissonnette, N.; Benchaar, C.; Zhao, X.; Lei, C.; Ibeagha-Awemu, E. Deep sequencing shows microRNA involvement in bovine mammary gland adaptation to diets supplemented with linseed oil or safflower oil. BMC Genom. 2015, 16, 884. [CrossRef] [PubMed]

33. Li, R.; Dudemaine, P.-L.; Zhao, X.; Lei, C.; Ibeagha-Awemu, E.M. Comparative analysis of the mirnome of bovine milk fat, whey and cells. PLoS ONE 2016, 11, e0154129. [CrossRef] [PubMed]

34. Li, R.; Zhang, C.-L.; Liao, X.-X.; Chen, D.; Wang, W.-Q.; Zhu, Y.-H.; Geng, X.-H.; Ji, D.-J.; Mao, Y.-J.; Gong, Y.-C.; et al. Transcriptome microRNA profiling of bovine mammary glands infected with Staphylococcus aureus. Int. J. Mol. Sci. 2015, 16, 4997-5013. [CrossRef] [PubMed]

35. Li, Z.; Liu, H.; Jin, X.; Lo, L.; Liu, J. Expression profiles of microRNAs from lactating and non-lactating bovine mammary glands and identification of miRNA related to lactation. BMC Genom. 2012, 13, 731. [CrossRef] [PubMed]

36. Wang, M.; Moisá, S.; Khan, M.J.; Wang, J.; Bu, D.; Loor, J.J. MicroRNA expression patterns in the bovine mammary gland are affected by stage of lactation. J. Dairy Sci. 2012, 95, 6529-6535. [CrossRef] [PubMed]

37. Wicik, Z.; Gajewska, M.; Majewska, A.; Walkiewicz, D.; Osińska, E.; Motyl, T. Characterization of microRNA profile in mammary tissue of dairy and beef breed heifers. J. Anim. Breed. Gen. 2016, 133, 31-42. [CrossRef] [PubMed]

38. Matboli, M.; Shafei, A.; Ali, M.; Kamal, K.M.; Noah, M.; Lewis, P.; Habashy, A.; Ehab, M.; Gaber, A.I.; Abdelzaher, H.M. Emerging role of nutrition and the non-coding landscape in type 2 diabetes mellitus: A review of literature. Gene 2018. [CrossRef] [PubMed]

39. Ruan, X. Long non-coding RNA central of glucose homeostasis. J. Cell. Biochem. 2016, 117, 1061-1065. [CrossRef] [PubMed]

40. Zhao, X.-Y.; Lin, J.D. Long noncoding RNAs: A new regulatory code in metabolic control. Trends Biochem. Sci. 2015, 40, 586-596. [CrossRef] [PubMed]

41. Yang, L.; Li, P.; Yang, W.; Ruan, X.; Kiesewetter, K.; Zhu, J.; Cao, H. Integrative transcriptome analyses of metabolic responses in mice define pivotal lncRNA metabolic regulators. Cell. Metabolism 2016, 24, 627-639. [CrossRef] [PubMed]

42. Xia, J.; Xin, L.; Zhu, W.; Li, L.; Li, C.; Wang, Y.; Mu, Y.; Yang, S.; Li, K. Characterization of long non-coding RNA transcriptome in high-energy diet induced nonalcoholic steatohepatitis minipigs. Sci. Rep. 2016, 6, 30709. [CrossRef] [PubMed] 
43. Weikard, R.; Hadlich, F.; Hammon, H.M.; Frieten, D.; Gerbert, C.; Koch, C.; Dusel, G.; Kuehn, C. Long noncoding RNAs are associated with metabolic and cellular processes in the jejunum mucosa of pre-weaning calves in response to different diets. Oncotarget 2018, 9, 21052-21069. [CrossRef] [PubMed]

44. Yang, F.; Huo, X.-S.; Yuan, S.-X.; Zhang, L.; Zhou, W.-P.; Wang, F.; Sun, S.-H. Repression of the long noncoding RNA-let by histone deacetylase 3 contributes to hypoxia-mediated metastasis. Mol. Cell 2013, 49, 1083-1096. [CrossRef] [PubMed]

45. Haug, A.; Høstmark, A.T.; Harstad, O.M. Bovine milk in human nutrition-a review. Lipids Health Dis. 2007, 6, 25. [CrossRef] [PubMed]

46. Lock, A.L.; Bauman, D.E. Modifying milk fat composition of dairy cows to enhance fatty acids beneficial to human health. Lipids 2004, 39, 1197-1206. [CrossRef] [PubMed]

47. Loor, J.; Ferlay, A.; Ollier, A.; Doreau, M.; Chilliard, Y. Relationship among trans and conjugated fatty acids and bovine milk fat yield due to dietary concentrate and linseed oil. J. Dairy Sci. 2005, 88, 726-740. [CrossRef]

48. Kelly, M.L.; Berry, J.R.; Dwyer, D.A.; Griinari, J.; Chouinard, P.Y.; Van Amburgh, M.E.; Bauman, D.E. Dietary fatty acid sources affect conjugated linoleic acid concentrations in milk from lactating dairy cows. J. Nutr. 1998, 128, 881-885. [CrossRef] [PubMed]

49. Glasser, F.; Ferlay, A.; Chilliard, Y. Oilseed lipid supplements and fatty acid composition of cow milk: A meta-analysis. J. Dairy Sci. 2008, 91, 4687-4703. [CrossRef] [PubMed]

50. Bell, J.; Griinari, J.; Kennelly, J. Effect of safflower oil, flaxseed oil, monensin, and vitamin e on concentration of conjugated linoleic acid in bovine milk fat. J. Dairy Sci. 2006, 89, 733-748. [CrossRef]

51. Ammah, A.A.; Benchaar, C.; Bissonnette, N.; Gévry, N.; Ibeagha-Awemu, E.M. Treatment and post-treatment effects of dietary supplementation with safflower oil and linseed oil on milk components and blood metabolites of canadian holstein cows. J. Appl. Anim. Res. 2018, 46, 898-906. [CrossRef]

52. Ammah, A.; Do, D.; Bissonnette, N.; Gévry, N.; Ibeagha-Awemu, E. Co-expression network analysis identifies miRNA-mRNA networks potentially regulating milk traits and blood metabolites. Int. J. Mol. Sci. 2018, 19, 2500. [CrossRef] [PubMed]

53. Ibeagha-Awemu, E.M.; Li, R.; Ammah, A.A.; Dudemaine, P.-L.; Bissonnette, N.; Benchaar, C.; Zhao, X. Transcriptome adaptation of the bovine mammary gland to diets rich in unsaturated fatty acids shows greater impact of linseed oil over safflower oil on gene expression and metabolic pathways. BMC Genom. 2016, 17, 104. [CrossRef] [PubMed]

54. Cabili, M.N.; Trapnell, C.; Goff, L.; Koziol, M.; Tazon-Vega, B.; Regev, A.; Rinn, J.L. Integrative annotation of human large intergenic noncoding RNAs reveals global properties and specific subclasses. Genes Dev. 2011, 25, 1915-1927. [CrossRef] [PubMed]

55. Derrien, T.; Johnson, R.; Bussotti, G.; Tanzer, A.; Djebali, S.; Tilgner, H.; Guernec, G.; Martin, D.; Merkel, A.; Knowles, D.G.; et al. The gencode v7 catalog of human long noncoding RNAs: Analysis of their gene structure, evolution, and expression. Genome Res. 2012, 22, 1775-1789. [CrossRef] [PubMed]

56. Guttman, M.; Donaghey, J.; Carey, B.W.; Garber, M.; Grenier, J.K.; Munson, G.; Young, G.; Lucas, A.B.; Ach, R.; Bruhn, L.; et al. LincRNAs act in the circuitry controlling pluripotency and differentiation. Nature 2011, 477, 295-300. [CrossRef] [PubMed]

57. Kotake, Y.; Nakagawa, T.; Kitagawa, K.; Suzuki, S.; Liu, N.; Kitagawa, M.; Xiong, Y. Long non-coding RNA anril is required for the prc2 recruitment to and silencing of p15(ink4b) tumor suppressor gene. Oncogene 2011, 30, 1956-1962. [CrossRef] [PubMed]

58. Maamar, H.; Cabili, M.N.; Rinn, J.; Raj, A. Linc-hoxa1 is a noncoding RNA that represses hoxa1 transcription in cis. Genes Dev. 2013, 27, 1260-1271. [CrossRef] [PubMed]

59. Ponjavic, J.; Oliver, P.L.; Lunter, G.; Ponting, C.P. Genomic and transcriptional co-localization of protein-coding and long non-coding RNA pairs in the developing brain. PLoS Genet. 2009, 5, e1000617. [CrossRef] [PubMed]

60. Rinn, J.L.; Kertesz, M.; Wang, J.K.; Squazzo, S.L.; Xu, X.; Brugmann, S.A.; Goodnough, L.H.; Helms, J.A.; Farnham, P.J.; Segal, E.; et al. Functional demarcation of active and silent chromatin domains in human hox loci by noncoding RNAs. Cell 2007, 129, 1311-1323. [CrossRef] [PubMed]

61. Wang, K.C.; Yang, Y.W.; Liu, B.; Sanyal, A.; Corces-Zimmerman, R.; Chen, Y.; Lajoie, B.R.; Protacio, A.; Flynn, R.A.; Gupta, R.A.; et al. A long noncoding RNA maintains active chromatin to coordinate homeotic gene expression. Nature 2011, 472, 120-124. [CrossRef] [PubMed] 
62. Ebisuya, M.; Yamamoto, T.; Nakajima, M.; Nishida, E. Ripples from neighbouring transcription. Nat. Cell Biol. 2008, 10, 1106-1113. [CrossRef] [PubMed]

63. Carpenter, S.; Aiello, D.; Atianand, M.K.; Ricci, E.P.; Gandhi, P.; Hall, L.L.; Byron, M.; Monks, B.; Henry-Bezy, M.; Lawrence, J.B. A long noncoding RNA mediates both activation and repression of immune response genes. Science 2013, 341, 789-792. [CrossRef] [PubMed]

64. Fitzgerald, K.A.; Caffrey, D.R. Long noncoding RNAs in innate and adaptive immunity. Curr. Opin. Immunol. 2014, 26, 140-146. [CrossRef] [PubMed]

65. Yang, W.; Li, X.; Qi, S.; Li, X.; Zhou, K.; Qing, S.; Zhang, Y.; Gao, M.-Q. LncRNA h19 is involved in tgf- $\beta 1$-induced epithelial to mesenchymal transition in bovine epithelial cells through pi3k/akt signaling pathway. Peer] 2017, 5, e3950. [CrossRef] [PubMed]

66. Ma, Q.; Li, L.; Tang, Y.; Fu, Q.; Liu, S.; Hu, S.; Qiao, J.; Chen, C.; Ni, W. Analyses of long non-coding RNAs and mRNA profiling through RNA sequencing of mdbk cells at different stages of bovine viral diarrhea virus infection. Res. Vet. Sci. 2017, 115, 508-516. [CrossRef] [PubMed]

67. Flintoft, L. Non-coding RNA: Structure and function for lncRNAs. Nat. Rev. Genet. 2013, 14, 598. [CrossRef] [PubMed]

68. Callahan, R.; Raafat, A. Notch signaling in mammary gland tumorigenesis. J. Mammary Gland Biol. Neoplasia 2001, 6, 23-36. [CrossRef] [PubMed]

69. Callahan, R.; Egan, S.E. Notch signaling in mammary development and oncogenesis. J. Mammary Gland Biol. Neoplasia 2004, 9, 145-163. [CrossRef] [PubMed]

70. Do, D.; Dudemaine, P.-L.; Li, R.; Ibeagha-Awemu, E. Co-expression network and pathway analyses reveal important modules of miRNAs regulating milk yield and component traits. Int. J. Mol. Sci. 2017, 18, 1560. [CrossRef] [PubMed]

71. Lee, M.; Kim, H.J.; Kim, S.W.; Park, S.-A.; Chun, K.-H.; Cho, N.H.; Song, Y.S.; Kim, Y.T. The long non-coding RNA hotair increases tumour growth and invasion in cervical cancer by targeting the notch pathway. Oncotarget 2016, 7, 44558. [CrossRef] [PubMed]

72. Cai, H.; Reinisch, K.; Ferro-Novick, S. Coats, tethers, rabs, and snares work together to mediate the intracellular destination of a transport vesicle. Dev. Cell 2007, 12, 671-682. [CrossRef] [PubMed]

73. Pfeffer, S.R. Transport vesicle docking: Snares and associates. Annu. Rev. Cell Dev. Biol. 1996, 12, $441-461$. [CrossRef] [PubMed]

74. Chen, Y.A.; Scheller, R.H. Snare-mediated membrane fusion. Nat. Rev. Mol. Cell Biol. 2001, 2, 98. [CrossRef] [PubMed]

75. Do, D.N.; Bissonnette, N.; Lacasse, P.; Miglior, F.; Sargolzaei, M.; Zhao, X.; Ibeagha-Awemu, E. Genome-wide association analysis and pathways enrichment for lactation persistency in canadian holstein cattle. J. Dairy Sci. 2017, 100, 1955-1970. [CrossRef] [PubMed]

76. Do, D.N.; Li, R.; Dudemaine, P.-L.; Ibeagha-Awemu, E.M. MicroRNA roles in signalling during lactation: An insight from differential expression, time course and pathway analyses of deep sequence data. Sci. Rep. 2017, 7, 44605. [CrossRef] [PubMed]

77. Benchaar, C.; Romero-Pérez, G.A.; Chouinard, P.Y.; Hassanat, F.; Eugene, M.; Petit, H.V.; Côrtes, C. Supplementation of increasing amounts of linseed oil to dairy cows fed total mixed rations: Effects on digestion, ruminal fermentation characteristics, protozoal populations, and milk fatty acid composition. J. Dairy Sci. 2012, 95, 4578-4590. [CrossRef] [PubMed]

78. Palmquist, D.L.; Lock, A.L.; Shingfield, K.J.; Bauman, D.E. Biosynthesis of conjugated linoleic acid in ruminants and humans. Adv. Food Nutr. Res. 2005, 50, 179-217. [PubMed]

79. Jacobs, A.A.A.; van Baal, J.; Smits, M.A.; Taweel, H.Z.H.; Hendriks, W.H.; van Vuuren, A.M.; Dijkstra, J. Effects of feeding rapeseed oil, soybean oil, or linseed oil on stearoyl-coa desaturase expression in the mammary gland of dairy cows. J. Dairy Sci. 2011, 94, 874-887. [CrossRef] [PubMed]

80. Soccio, R.E.; Breslow, J.L. Star-related lipid transfer (start) proteins: Mediators of intracellular lipid metabolism. J. Biol. Chem. 2003, 278, 22183-22186. [CrossRef] [PubMed]

81. Tang, F.; Zhang, R.; He, Y.; Zou, M.; Guo, L.; Xi, T. MicroRNA-125b induces metastasis by targeting stard13 in mcf-7 and mda-mb-231 breast cancer cells. PLoS ONE 2012, 7, e35435. [CrossRef] [PubMed]

82. Liu, Q.; Zheng, J.; Yin, D.D.; Xiang, J.; He, F.; Wang, Y.C.; Liang, L.; Qin, H.Y.; Liu, L.; Liang, Y.M.; et al. Monocyte to macrophage differentiation-associated (mmd) positively regulates erk and akt activation and tnf-alpha and no production in macrophages. Mol. Biol. Rep. 2012, 39, 5643-5650. [CrossRef] [PubMed] 
83. Benjamini, Y.; Hochberg, Y. Controlling the false discovery rate: A practical and powerful approach to multiple testing. J. R. Stat. Soc. Ser. B Stat. Methodol. 1995, 57, 289-300.

84. Huang, D.W.; Sherman, B.T.; Lempicki, R.A. Bioinformatics enrichment tools: Paths toward the comprehensive functional analysis of large gene lists. Nucleic Acids Res. 2009, 37, 1-13. [CrossRef] [PubMed]

85. Young, M.D.; Wakefield, M.J.; Smyth, G.K.; Oshlack, A. Gene ontology analysis for RNA-seq: Accounting for selection bias. Genome Biol. 2010, 11, R14. [CrossRef] [PubMed]

86. Bindea, G.; Mlecnik, B.; Hackl, H.; Charoentong, P.; Tosolini, M.; Kirilovsky, A.; Fridman, W.H.; Pages, F.; Trajanoski, Z.; Galon, J. Cluego: A cytoscape plug-in to decipher functionally grouped gene ontology and pathway annotation networks. Bioinformatics 2009, 25, 1091-1093. [CrossRef] [PubMed]

87. Farr, V.C.; Stelwagen, K.; Cate, L.R.; Molenaar, A.J.; McFadden, T.B.; Davis, S.R. An improved method for the routine biopsy of bovine mammary tissue. J. Dairy Sci. 1996, 79, 543-549. [CrossRef]

88. Zimin, A.V.; Delcher, A.L.; Florea, L.; Kelley, D.R.; Schatz, M.C.; Puiu, D.; Hanrahan, F.; Pertea, G.; Van Tassell, C.P.; Sonstegard, T.S. A whole-genome assembly of the domestic cow, bos taurus. Genome Biol. 2009, 10, R42. [CrossRef] [PubMed]

89. Kim, D.; Pertea, G.; Trapnell, C.; Pimentel, H.; Kelley, R.; Salzberg, S.L. Tophat2: Accurate alignment of transcriptomes in the presence of insertions, deletions and gene fusions. Genome Biol. 2013, 14, R36. [CrossRef] [PubMed]

90. Trapnell, C.; Roberts, A.; Goff, L.; Pertea, G.; Kim, D.; Kelley, D.R.; Pimentel, H.; Salzberg, S.L.; Rinn, J.L.; Pachter, L. Differential gene and transcript expression analysis of RNA-seq experiments with tophat and cufflinks. Nat. Protocols 2012, 7, 562. [CrossRef] [PubMed]

91. Sun, L.; Luo, H.; Bu, D.; Zhao, G.; Yu, K.; Zhang, C.; Liu, Y.; Chen, R.; Zhao, Y. Utilizing sequence intrinsic composition to classify protein-coding and long non-coding transcripts. Nucleic Acids Res. 2013, 41, e166. [CrossRef] [PubMed]

92. Wang, L.; Park, H.J.; Dasari, S.; Wang, S.; Kocher, J.-P.; Li, W. Cpat: Coding-potential assessment tool using an alignment-free logistic regression model. Nucleic Acids Res. 2013, 41, e74. [CrossRef] [PubMed]

93. Zhao, Y.; Li, H.; Fang, S.; Kang, Y.; Wu, W.; Hao, Y.; Li, Z.; Bu, D.; Sun, N.; Zhang, M.Q.; et al. Noncode 2016: An informative and valuable data source of long non-coding RNAs. Nucleic Acids Res. 2016, 44, D203-D208. [CrossRef] [PubMed]

94. Edgar, R.C. Search and clustering orders of magnitude faster than blast. Bioinformatics 2010, 26, $2460-2461$. [CrossRef] [PubMed]

95. Bu, D.; Yu, K.; Sun, S.; Xie, C.; Skogerbø, G.; Miao, R.; Xiao, H.; Liao, Q.; Luo, H.; Zhao, G. Noncode v3.0: Integrative annotation of long noncoding RNAs. Nucleic Acids Res. 2011, 40, D210-D215. [CrossRef] [PubMed]

96. Quinlan, A.R.; Hall, I.M. Bedtools: A flexible suite of utilities for comparing genomic features. Bioinformatics 2010, 26, 841-842. [CrossRef] [PubMed]

97. Shannon, P.; Markiel, A.; Ozier, O.; Baliga, N.S.; Wang, J.T.; Ramage, D.; Amin, N.; Schwikowski, B.; Ideker, T. Cytoscape: A software environment for integrated models of biomolecular interaction networks. Genome Res. 2003, 13, 2498-2504. [CrossRef] [PubMed]

98. Love, M.I.; Huber, W.; Anders, S. Moderated estimation of fold change and dispersion for RNA-seq data with deseq2. Genome Biol. 2014, 15, 550. [CrossRef] [PubMed]

99. Livak, K.J.; Schmittgen, T.D. Analysis of relative gene expression data using real-time quantitative pcr and the 2- $\delta$ ct method. Methods 2001, 25, 402-408. [CrossRef] [PubMed]

(C) 2018 by the her Majesty the Queen in Right of Canada as represented by the Minister of Agriculture and Agri-Food. Licensee MDPI, Basel, Switzerland. This article is an open access article distributed under the terms and conditions of the Creative Commons Attribution (CC BY) license (http://creativecommons.org/licenses/by/4.0/). 